\title{
Single-cell transcriptional analysis of normal, aberrant, and malignant hematopoiesis in zebrafish
}

\section{Citation}

Moore, F. E., E. G. Garcia, R. Lobbardi, E. Jain, Q. Tang, J. C. Moore, M. Cortes, et al. 2016. "Single-cell transcriptional analysis of normal, aberrant, and malignant hematopoiesis in zebrafish." The Journal of Experimental Medicine 213 (6): 979-992. doi:10.1084/jem. 20152013. http://dx.doi.org/10.1084/jem.20152013.

\section{Published Version}

doi:10.1084/jem.20152013

\section{Permanent link}

http://nrs.harvard.edu/urn-3:HUL.InstRepos:29626146

\section{Terms of Use}

This article was downloaded from Harvard University's DASH repository, and is made available under the terms and conditions applicable to Other Posted Material, as set forth at http:// nrs.harvard.edu/urn-3:HUL.InstRepos:dash.current.terms-of-use\#LAA

\section{Share Your Story}

The Harvard community has made this article openly available.

Please share how this access benefits you. Submit a story.

Accessibility 


\title{
Single-cell transcriptional analysis of normal, aberrant, and malignant hematopoiesis in zebrafish
}

\author{
Finola E. Moore, ${ }^{1 *}$ Elaine G. Garcia, ${ }^{1 *}$ Riadh Lobbardi, ${ }^{1}$ Esha Jain, ${ }^{3}$ Qin Tang,,${ }^{1}$ John C. Moore, ${ }^{1}$ \\ Mauricio Cortes,${ }^{5}$ Aleksey Molodtsov, ${ }^{1}$ Melissa Kasheta,${ }^{6}$ Christina C. Luo, ${ }^{1}$ Amaris J. Garcia, ${ }^{1}$ \\ Ravi Mylvaganam, ${ }^{1}$ Jeffrey A. Yoder, ${ }^{7}$ Jessica S. Blackburn, ${ }^{8,9,10,11}$ Ruslan I. Sadreyev, ${ }^{4,12}$ Craig J. Ceol, ${ }^{6}$ \\ Trista E. North, ${ }^{5}$ and David M. Langenau ${ }^{1,2,3,13}$
}

\author{
'Molecular Pathology and ${ }^{2}$ Cancer Center, Massachusetts General Hospital, Charlestown, MA 02129 \\ ${ }^{3}$ Center for Regenerative Medicine and ${ }^{4}$ Department of Molecular Biology, Massachusetts General Hospital, Boston, MA 02114 \\ ${ }^{5}$ Department of Pathology, Beth Israel Deaconess Medical Center and Harvard Medical School, Boston, MA 02115 \\ ${ }^{6}$ Program in Molecular Medicine and Department of Molecular, Cell and Cancer Biology, University of Massachusetts Medical School, Worcester, MA 01605 \\ ${ }^{7}$ Department of Molecular Biomedical Sciences, North Carolina State University, Raleigh, NC 27607 \\ ${ }^{8}$ Department of Pathology, ${ }^{9}$ Department of Biochemistry, ${ }^{10}$ Department of Molecular Biology, and ${ }^{11}$ Department of Molecular and Cellular Biochemistry, University \\ of Kentucky College of Medicine, Lexington, KY 40536 \\ ${ }^{12}$ Department of Pathology, Massachusetts General Hospital and Harvard Medical School, Boston, MA 02114 \\ ${ }^{13}$ Harvard Stem Cell Institute, Cambridge, MA 02139
}

\begin{abstract}
Hematopoiesis culminates in the production of functionally heterogeneous blood cell types. In zebrafish, the lack of cell surface antibodies has compelled researchers to use fluorescent transgenic reporter lines to label specific blood cell fractions. However, these approaches are limited by the availability of transgenic lines and fluorescent protein combinations that can be distinguished. Here, we have transcriptionally profiled single hematopoietic cells from zebrafish to define erythroid, myeloid, $\mathrm{B}$, and T cell lineages. We also used our approach to identify hematopoietic stem and progenitor cells and a novel $N K$-lysin $4^{+}$ cell type, representing a putative cytotoxic T/NK cell. Our platform also quantified hematopoietic defects in rag2 ${ }^{E 450 f s}$ mutant fish and showed that these fish have reduced T cells with a subsequent expansion of $N K$-lysin $4^{+}$cells and myeloid cells. These data suggest compensatory regulation of the innate immune system in rag2 ${ }^{E 450 f s}$ mutant zebrafish. Finally, analysis of Myc-induced T cell acute lymphoblastic leukemia showed that cells are arrested at the $\mathrm{CD} 4^{+} / \mathrm{CD} 8^{+}$cortical thymocyte stage and that a subset of leukemia cells inappropriately reexpress stem cell genes, including bmi 1 and $c m y b$. In total, our experiments provide new tools and biological insights into single-cell heterogeneity found in zebrafish blood and leukemia.
\end{abstract}

Cell differentiation is a complex process that results in the production of widely heterogeneous and functionally distinct cell populations. The individual cell fate decisions that create cell heterogeneity are best understood at single-cell resolution, especially within blood where hematopoiesis culminates in the production of a variety of functionally diverse cells. Blood cell lineages and leukemia cell subfractions from mouse and human have been commonly identified using cell surface antibodies and FACS. Building off these approaches, investigators have used increasingly complex strategies to define blood cell heterogeneity, including multiparameter flow cytometry and mass cytometry (Irish et al., 2006; Kotecha et al., 2008; Bendall et al., 2011, 2014; Fathman et al., 2011; Gibbs et al., 2011; Amir el et al., 2013; Lacayo et al., 2013; Litjens et al., 2013; Shalek et al., 2013, 2014; Sen et al., 2014;

\footnotetext{
${ }^{*}$ Finola E. Moore and Elaine G. Garcia contributed equally.
}

Correspondence to David M. Langenau: dlangenau@mgh.harvard.edu; or Finola E. Moore: femoore@mgh.harvard.edu

Abbreviations used: CTL, cytotoxic T lymphocyte; HSPC, hematopoietic stem and progenitor cell; LPC, leukemia-propagating cell; qPCR, quantitative PCR; T-ALL, T-cell acute Iymphoblastic leukemia; WGCNA, Weighted Gene Co-Expression Network Analysis; WKM, whole-kidney marrow.
Levine et al., 2015). Single-cell transcriptional profiling has also been used to assess blood cell heterogeneity and leukemia (Flatz et al., 2011; Guo et al., 2013; Moignard et al., 2013; Riddell et al., 2014; Saadatpour et al., 2014; Fan et al., 2015; Wilson et al., 2015). For instance, Flatz et al. (2011) used single-cell quantitative PCR (qPCR) to identify new subsets of $\mathrm{CD}^{+} \mathrm{T}$ cells and studied their response to different vaccines. Heterogeneity within leukemia and acquisition of novel gene programs have also been described using this approach (Guo et al., 2013; Saadatpour et al., 2014). Despite the plethora of techniques used to assess blood cell heterogeneity in mice and humans, these single-cell transcriptional profiling approaches have yet to be widely adapted to other experimental models, including the zebrafish.

Zebrafish have emerged as a robust model for studying hematopoiesis, immunity, and cancer. Best known for its utility in forward genetic screens, the zebrafish has contributed immensely to our understanding of blood development. For example, a forward genetic screen identified ferroportin as a

- 2016 Moore et al. This article is distributed under the terms of an Attribution-Noncommercial-Share Alike-No Mirror Sites license for the first six months after the publication date (see http://www.rupress.org Alike-No Mirror Sites license for the first six months after the publication date (see http://www.rupress.org
/terms). After six months it is available under a Creative Commons License (Attribution-NoncommercialShare Alike 3.0 Unported license, as described at http://creativecommons.org/licenses/by-nc-sa/3.0/). 
novel iron exporter (Donovan et al., 2000), and mutations in this gene were subsequently found to be a common cause of inherited disorders of iron overload in humans (Pietrangelo, 2004). Zebrafish have also become a facile and powerful model for discovering novel drugs that affect blood and leukemia growth. For example, North et al. (2007) identified prostaglandin as a potent inducer of hematopoietic stem cells. Di-methyl PGE2 is currently in Phase II clinical trials to improve transplantation of human umbilical cord blood (Goessling et al., 2011; Cutler et al., 2013). Beyond normal hematopoiesis, immune-compromised zebrafish have been developed as models of severe combined immunodeficiency (Wienholds et al., 2002; Jima et al., 2009; Petrie-Hanson et al., 2009; Tang et al., 2014). Finally, a wide range of zebrafish blood malignancies has been developed including $\mathrm{T}$ cell acute lymphoblastic leukemia (T-ALL; Langenau et al., 2003, 2005; Chen et al., 2007; Feng et al., 2007; Frazer et al., 2009; Gutierrez et al., 2011). Using these models and chemical screening approaches, investigators have discovered new pathways and novel drugs that differentiate or kill leukemia cells (Yeh et al., 2009; Ridges et al., 2012; Blackburn et al., 2014; Gutierrez et al., 2014).

Despite the clear advantages of the zebrafish model for studying hematopoiesis and leukemia, the lack of lineagespecific cell surface antibodies remains a major hurdle for the field. Rather, analysis of heterogeneity has been largely limited to morphological assessment of blood cells after cytospin or by FACS that can discriminate cells based on size and granularity (Traver et al., 2003). Fluorescent transgenic reporter lines provide a more detailed understanding of blood development by labeling specific cell lineages. For example, Page et al. (2013) delineated different stages of B cell development in adult zebrafish using a dual fluorescent transgenic $\operatorname{Tg}(\mathrm{rag} 2: \mathrm{ds} R \mathrm{ed})$; $\operatorname{Tg}(\operatorname{IgM}: \mathrm{e} G F P)$ line; yet these approaches could not distinguish between mature $\mathrm{T}$ lymphocytes, myeloid cells, and erythroid cells within the same animal.These experiments illustrate the state of our field, where reliance on identifying blood cell lineages is limited by the precision with which transgenic promoters label cells and by the availability of fluorophores that can be distinguished by FACS or confocal imaging.

Here, we developed a transcriptional profiling approach that robustly characterizes single-cell heterogeneity in a wide range of blood cell types. Using the Fluidigm single-cell quantitative (qPCR) platform, we systematically categorized the major blood cell lineages. We have also characterized hematopoietic stem and progenitor cells (HSPCs) and NK-lysin $4^{+}$ cells (nkl.4), representing a putative cytotoxic T/NK cell population. Our platform also impartially assessed hematopoietic defects in $\mathrm{T}$ cell-deficient rag2 $2^{E 450 f s}$ zebrafish. Finally, our work revealed that zebrafish Myc-induced T-ALL cells are arrested at the immature $\mathrm{CD} 4^{+} / \mathrm{CD} 8^{+}$double positive stage and that only a subset of leukemia cells reactivate stem cell genes, including bmi1 and cmyb. In total, our experiments provide facile and robust methods to transcriptionally profile zebrafish blood lineages at single-cell resolution. We also provide new insights into the biology of hematopoiesis in the zebrafish model.

\section{RESULTS}

Identifying diverse blood cell types using single-cell qPCR

To transcriptionally profile blood cell types in adult zebrafish, we first optimized a set of 96 primer pairs, comprising 50 genes that include well-known markers for specific blood cell lineages, candidate markers for undefined cell types of interest, and housekeeping genes. qPCR was completed using the Fluidigm BioMark microfluidics platform (Table S1). To substantiate calls made by qPCR, multiple primers for each gene were analyzed when possible. Not unexpectedly, $90 \%$ of primers for the same gene clustered immediately next to one another when assessed by row distance matrix analysis ( $n=27$ of 30 genes). BioMark results were also highly reproducible as assessed by technical replicates of bulk cDNA and replicate analysis of single cells completed on different days $\left(\mathrm{r}^{2}=0.93 ; n=69\right.$ single cells analyzed).

Single cells from WT whole-kidney marrow (WKM), the site of hematopoiesis in adult zebrafish, were isolated by FACS and transcriptionally profiled. Data were then subjected to unsupervised hierarchical clustering, which identified four major gene expression clusters that comprised erythroid, myeloid, B, and T lymphoid cells (Fig. $1 \mathrm{~A}$, gene order is the same for all heat maps and is provided in Table S2). Weighted gene co-expression network analysis (WGCNA) independently revealed four major clusters of genes that correlate with specific blood lineages (Fig. 1, B and C; and Fig. S1). Violin plots showed the distribution of cells expressing each gene transcript, allowing independent assessment of cells assigned to specific cell lineages (Fig. 1 D). As expected, the majority of cells characterized as erythroid by hierarchical clustering analysis expressed erythroid-specific genes, including $\beta$ A1 globin (ba1), solute carrier family 4 (anion exchanger, slc4a1al band3), and spectrin $\beta$ erythrocytic (sptb; $\mathrm{P}=5.67 \times 10^{-168}$ and $8.88 \times 10^{-64}, 1.57 \times 10^{-43}$, respectively, by ANOVA). Similarly, cells in the myeloid cluster expressed high levels of myeloid-specific peroxidase (mpx), lysozyme $C$ (lyz), and carboxypeptidase a5 (cpa5; $\mathrm{P}=4.31 \times 10^{-73}, 2.70 \times 10^{-71}$, and $1.67 \times 10^{-62}$, respectively, by ANOVA). Single-cell qPCR was also able to distinguish $\mathrm{T}$ from $\mathrm{B}$ cells within the same animal. This is particularly important because standard flow cytometry using forward and side scatter or morphological analysis of cytospins cannot discriminate these populations within bulk marrow cells of the same zebrafish (Traver et al., 2003). T cells expressed $T$ cell receptor $\alpha$ (tcra), lymphocyte-specific protein-tyrosine kinase (lck), and interleukin 7 receptor (il7r/ cd127; P $=3.24 \times 10^{-116}, 2.64 \times 10^{-30}$, and $4.48 \times 10^{-24}$, respectively, by ANOVA), whereas B cells commonly expressed paired box 5 (pax5), cd37, and $c d 79 a\left(\mathrm{P}=1.45 \times 10^{-43}, 1.19\right.$ $\times 10^{-82}$, and $1.30 \times 10^{-79}$, respectively, by ANOVA).

To confirm our ability to discern specific blood cell lineages by transcriptional profiling, hematopoietic cells from 

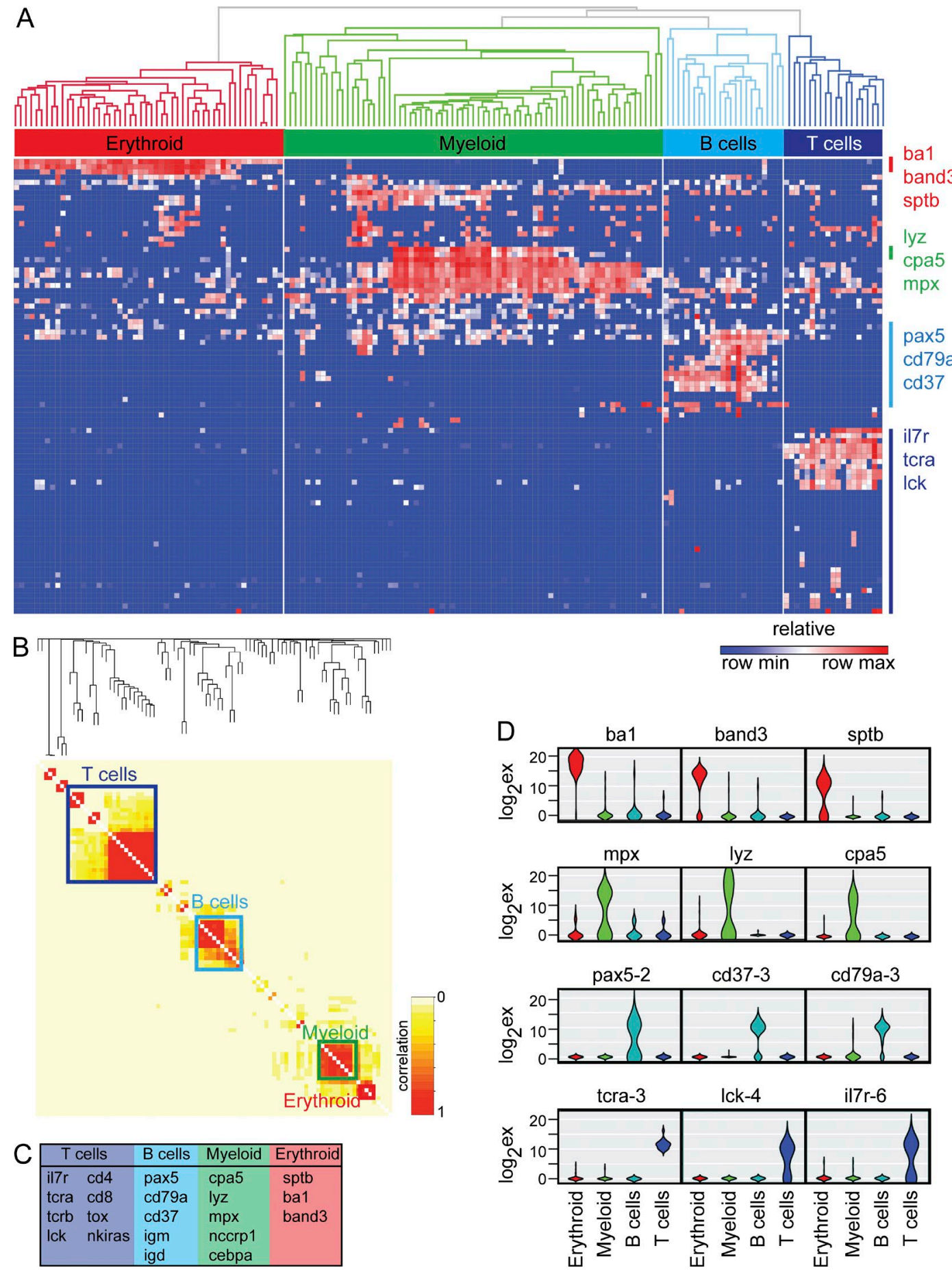

relative

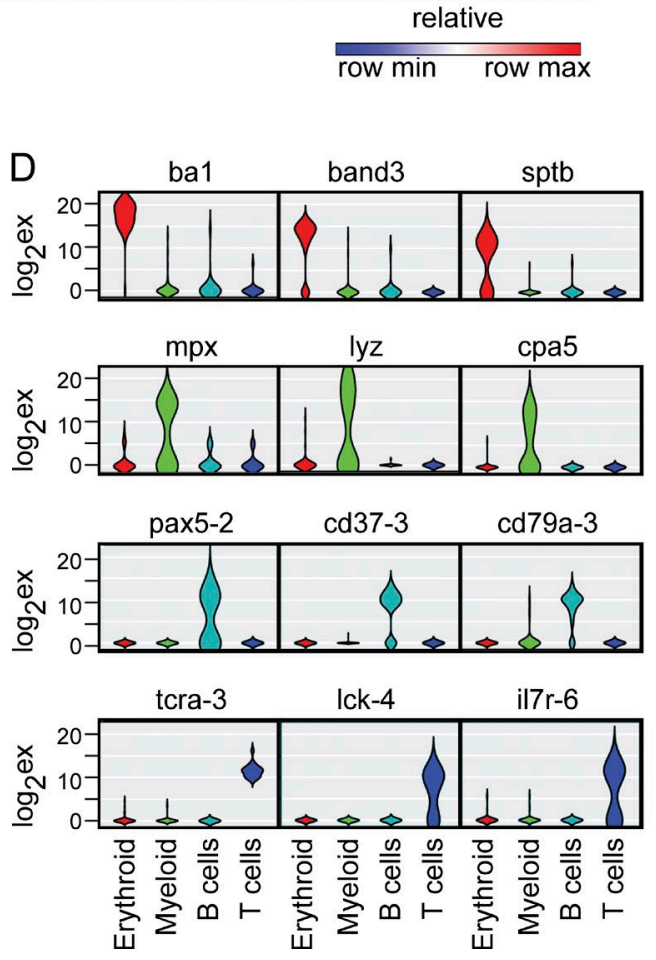

Figure 1. Single-cell qPCR delineates four major blood cell lineages from adult zebrafish marrow. (A) Unsupervised hierarchical clustering after gene expression analysis of single blood cells isolated from the whole kidney marrow. Heat map shows high transcript expression in red and low/absent expression in blue. Four major clusters were identified, including the following: erythroid (red), myeloid (green), B cells (light blue), and T cells (dark blue). Select lineage-specific genes are shown on the right. $n=166$ WKM cells combined from two animals. (B) WGCNA-identified genes that were expressed together in single cells. Each row and column corresponds to a specific gene primer set. The heat map represents WCGNA adjacency dissimilarity values in the range between 0 (low topological overlap, light yellow) and 1 (high topological overlap, dark red). (C) The genes in each lineage module from WGCNA are noted. (D) Violin plots show the distribution of gene expression of single cells. Cells types were assigned based on hierarchical clustering and assessed for transcript expression of well-known blood cell lineage genes. By ANOVA, ba 1 $\left(\mathrm{P}=5.67 \times 10^{-168}\right)$, s/c4a1a/band3 $\left(\mathrm{P}=8.88 \times 10^{-64}\right)$, sptb $\left(\mathrm{P}=1.57 \times 10^{-43}\right), \operatorname{mpx}\left(\mathrm{P}=4.31 \times 10^{-73}\right), \mathrm{lyz}\left(\mathrm{P}=2.70 \times 10^{-71}\right), \operatorname{cpa} 5\left(\mathrm{P}=1.67 \times 10^{-62}\right)$, pax5 $(\mathrm{P}=1.45 \times$ $\left.10^{-43}\right), c d 37\left(\mathrm{P}=1.19 \times 10^{-82}\right), \operatorname{cd} 79 a\left(\mathrm{P}=1.30 \times 10^{-79}\right)$, tcra $\left(\mathrm{P}=3.24 \times 10^{-116}, / c k\left(\mathrm{P}=2.64 \times 10^{-30}\right)\right.$, and il7r/cd127 $\left(\mathrm{P}=4.48 \times 10^{-24}\right)$. 


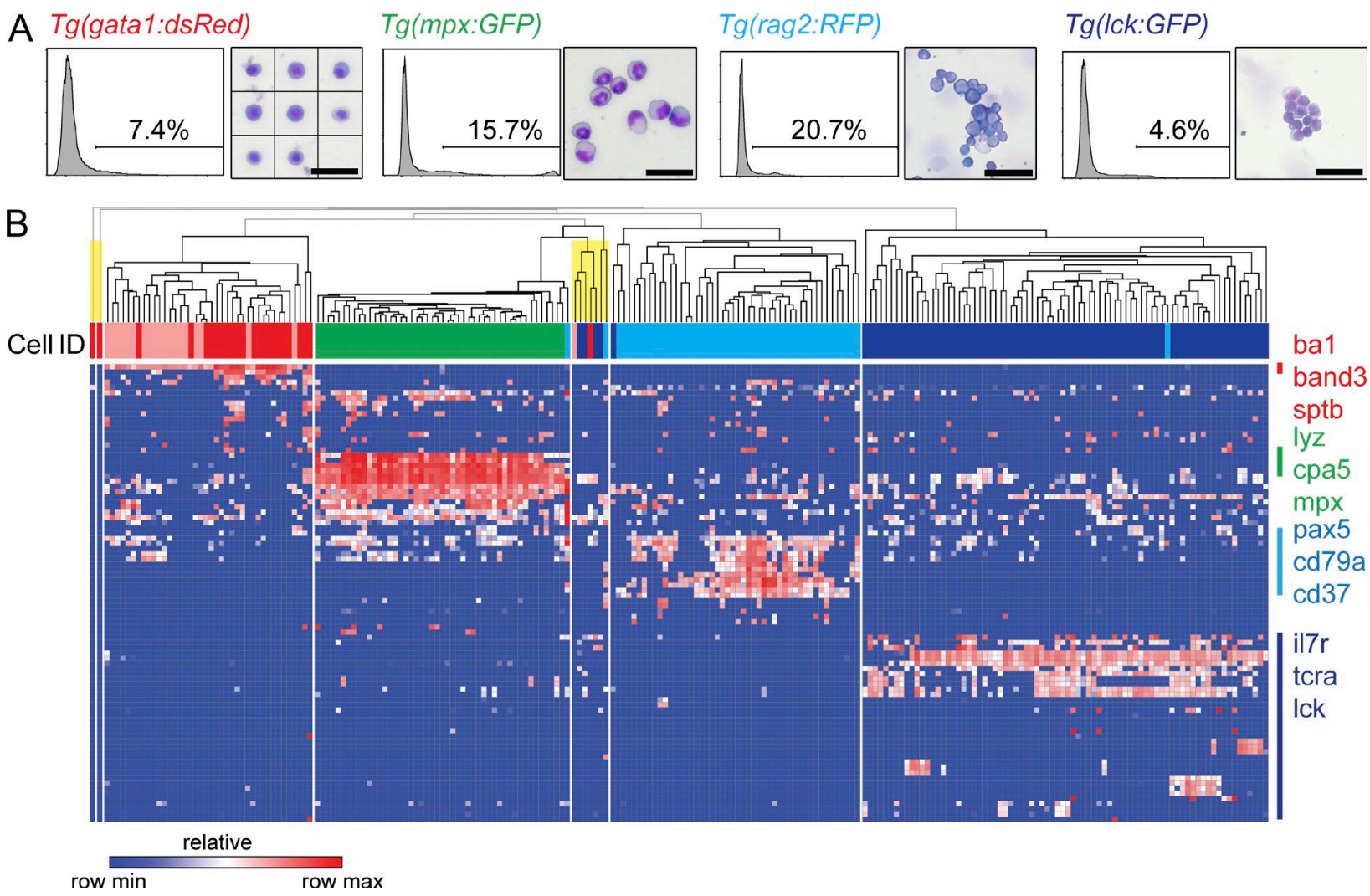

Figure 2. Single cells isolated from lineage-restricted transgenic reporter lines segregate together after hierarchical clustering. (A) FACS analysis (left) and cytospins of sorted transgenic blood populations (right). Bars, $25 \mu \mathrm{m}$. (B) Unsupervised hierarchical clustering after single-cell gene expression analysis. Cell identity is shown above the heat map: peripheral blood cells (pink, $n=20$ cells) and sorted fluorescent WKM cells from gata 1:dsRed (red, $n=24$ cells), mpx:GFP (green, $n=48$ cells), rag2:dsRed (light blue, $n=49$ cells), or Ick:GFP (dark blue, $n=83$ cells). Cells shown are from a single representative animal. Yellow shading denotes cells that failed to cluster into known lineages described by our qPCR panel.

adult fluorescent transgenic zebrafish and peripheral blood were compared. Erythroid cells were isolated by FACS from the peripheral blood of WT animals and the WKM of $T g$ (gata1:dsRed) animals ( $n=44$ cells). Neutrophils comprise a distinct subset of myeloid cells in the WKM and were isolated from $T g(m p x: G F P)$ animals ( $n=48$ cells). B cells and mature $\mathrm{T}$ cells were also isolated from WKM of $\mathrm{Tg}(\mathrm{rag} 2$ $: d s R e d)(n=49$ cells) and $T g(l c k: G F P)$ animals ( $n=83$ cells), respectively. Transgenic-labeled cell populations were represented at relative frequencies as previously reported (Fig. 2 A) and isolated to high purity after FACS ( $>92 \%$ purity, $>95 \%$ viability; Langenau et al., 2003, 2004; Traver et al., 2003; Lin et al., 2005; Mathias et al., 2006; Ma et al., 2012). Transcriptional profiling revealed that cells from each transgenic line largely clustered together after unsupervised hierarchical clustering (Fig. 2 B). Principal component analysis independently confirmed that transgenic and unlabeled WKM cells clustered tightly within each of the four major lineages (Fig. 3 A). Finally, $\geq 94 \%$ of transgeneexpressing cells were classified into their expected blood cell lineages after unsupervised hierarchical clustering with unlabeled WKM cells (Fig. 3 B and Fig. S2), confirming the specificity of transgenic lines, the high sort purity after FACS, and the accuracy of the qPCR calls. Violin plots confirmed distinct gene expression associated with each lineage (Fig. 3 C). Collectively, our results show that single-cell qPCR with our panel of markers reproducibly identifies distinct classes of blood cells within the WKM.

\section{Gene expression analysis of hematopoietic stem and precursor cells (HSPCs)}

Having used our platform to identify common blood cell lineages, we next wanted to characterize rare subpopulations of cells, including hematopoietic stem and precursor cells (HSPCs). $\operatorname{Tg}(C D 41: G F P)^{\text {low }}$ cells comprise $0.7 \%$ of the marrow and are HSPCs as determined by both gene expression and cell transplantation studies (Bertrand et al., 2008; Ma et al., 2011). Single blood cells were isolated from the GFP ${ }^{\text {low }}$ population of $\operatorname{Tg}(C D 41: G F P)$ WKM ( $n=85$ cells), and then compared with normal WKM ( $n=166$ cells). After unsupervised hierarchical clustering, the $C D 41: G F P^{\text {low }}$ cells clustered into two distinct populations (Fig. 4, A and B). The most prominent group clustered outside any of the previously defined lineages and expressed high levels of known stem cell genes including 

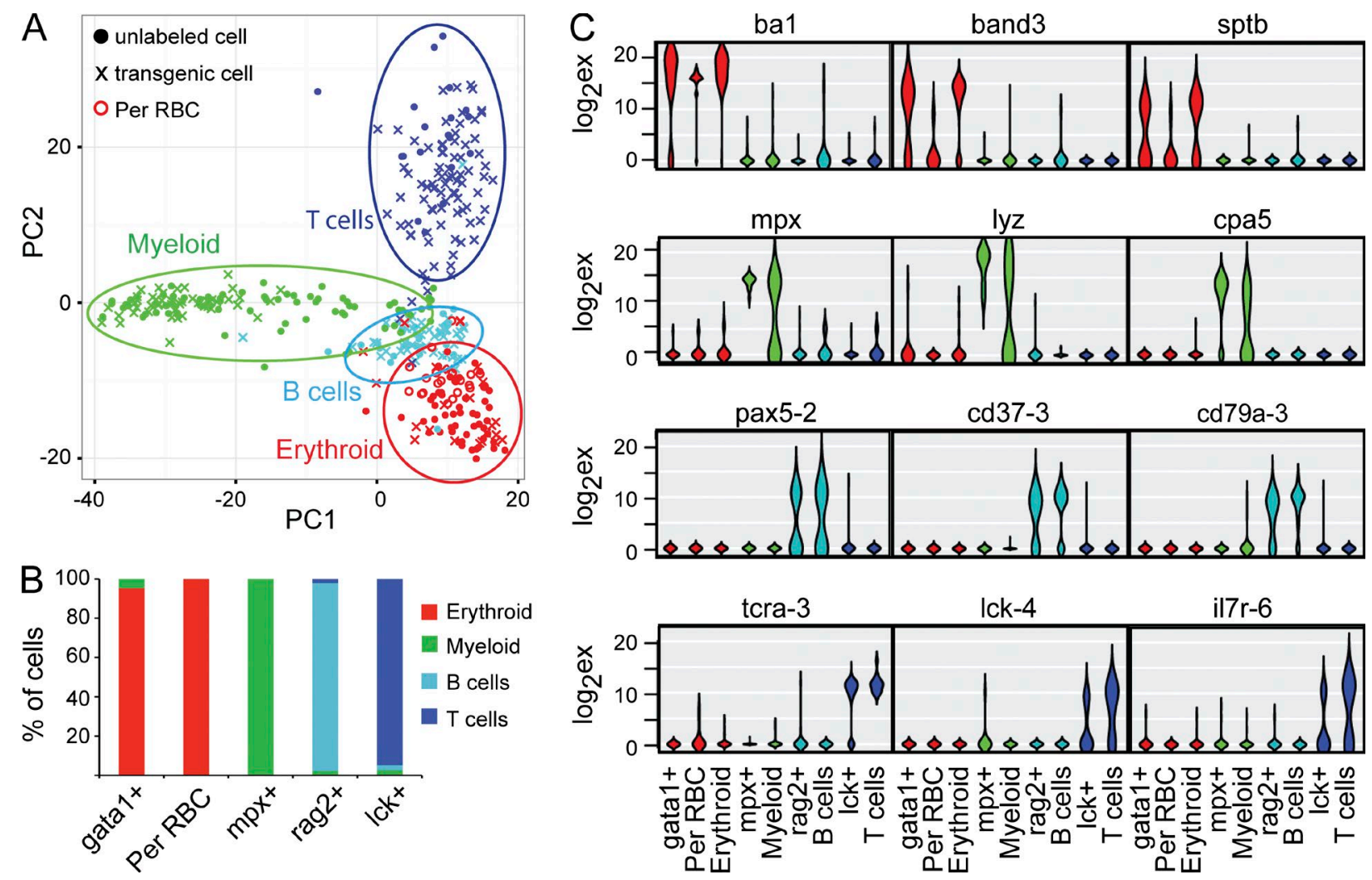

Figure 3. Unlabeled marrow cells cluster efficiently with single cells isolated from transgenic reporter lines. (A) Principal component analysis identifies four major blood lineages in WKM. Filled circles are unlabeled WKM, open circles are peripheral red blood cells. Cells isolated from transgenic reporter lines (gata 1:dsRed, red; mpx:GFP, green; rag2:dsRed, light blue; or Ick:GFP, dark blue) are denoted by an x. (B) Blood cells from transgenic fish reside within expected cell lineages as defined by hierarchical clustering with unlabeled marrow. (C) Violin plots confirm that cells assigned to specific hierarchical clusters have high expression of cell lineage-restricted genes. Unlabeled peripheral RBCs (per RBC) and marrow cells (erythroid, myeloid, B cells, and T cells). Sorted transgenic cells denoted by promoter.

LIM domain only 2 (lmo2), runt-related transcription factor 1 (runx1), and myeloblastosis viral oncogene homologue (cmyb; Fig. 4 A). As expected, these HSPCs largely failed to express differentiated blood cell lineage markers including ba1, mpx, pax5, and tcra (Fig. 4, A and D). A second group of CD41 :GFP $P^{\text {low }}$ cells loosely clustered with myeloid cells and failed to express the stem cell lineage markers including $\operatorname{lmo} 2$, runx 1 , and cmyb (Fig. 4 A). These cells also did not express prominent cell lineage markers for erythroid, myeloid, B, or T cells (Fig. 4 D), suggesting they are likely precursor cells that are transiting into mature cell lineages. In support of this interpretation, principal component analysis showed that the $C D 41: G F P^{\text {low }}$ cells cluster tightly together, independently of the other four dominant cell subfractions identified in the WKM (Fig. 4 C). Collectively, these data demonstrate that our approach can characterize rare HSPCs and identify previously undefined heterogeneity within CD41:GFP ${ }^{\text {low }}$ cells.

\section{Quantifying blood cell deficiencies in rag2-hypomorphic zebrafish}

We next used our approach to define alterations in blood cell lineage differentiation in mutant zebrafish. rag2 $2^{E 450 f s} \mathrm{mu}-$ tant zebrafish contain a hypomorphic mutation in the plant homeodomain; similar mutations in human are associated with severe combined immunodeficiency and Omenn Syndrome (Villa et al., 1999; Tang et al., 2014). Bulk WKM analysis previously revealed that $\mathrm{rag} 2^{\text {E450fS }}$ mutant zebrafish have reduced expression of mature $\mathrm{T}$ and $\mathrm{B}$ cell-specific genes, reduced lymphocyte cell counts as assessed by cytospin analysis, and variable effects on $\mathrm{T}$ and $\mathrm{B}$ cell receptor recombination (Tang et al., 2014); yet definitive loss of either lymphocyte cell type has not been reported. Single-cell transcriptional profiling of rag $2^{E 450 f 5} \mathrm{WKM}$ cells revealed a striking lack of mature T cells (Fig. 5, A and B; and Fig. S3; P = 0.0001, Fisher's exact test). rag2 ${ }^{E 450 f s}$ mutant fish had no alteration in the proportion of $\mathrm{B}$ cells contained within the marrow when compared with WT control animals (Fig. 5, A and B; and Fig. S3; P = 0.335, Fisher's exact test). These single-cell gene expression studies are consistent with the lack of $T$ cell receptor $\beta$ (tcrb) recombination, but largely normal $\operatorname{IgM}$ rearrangements in rag2 $2^{E 450 \text { s }}$ mutant fish (Tang et al., 2014).

Cytotoxic innate immune cells, including NK cells and cytotoxic T lymphocytes (CTLs), have long been postulated to exist in zebrafish, but have yet to be identified. Because 

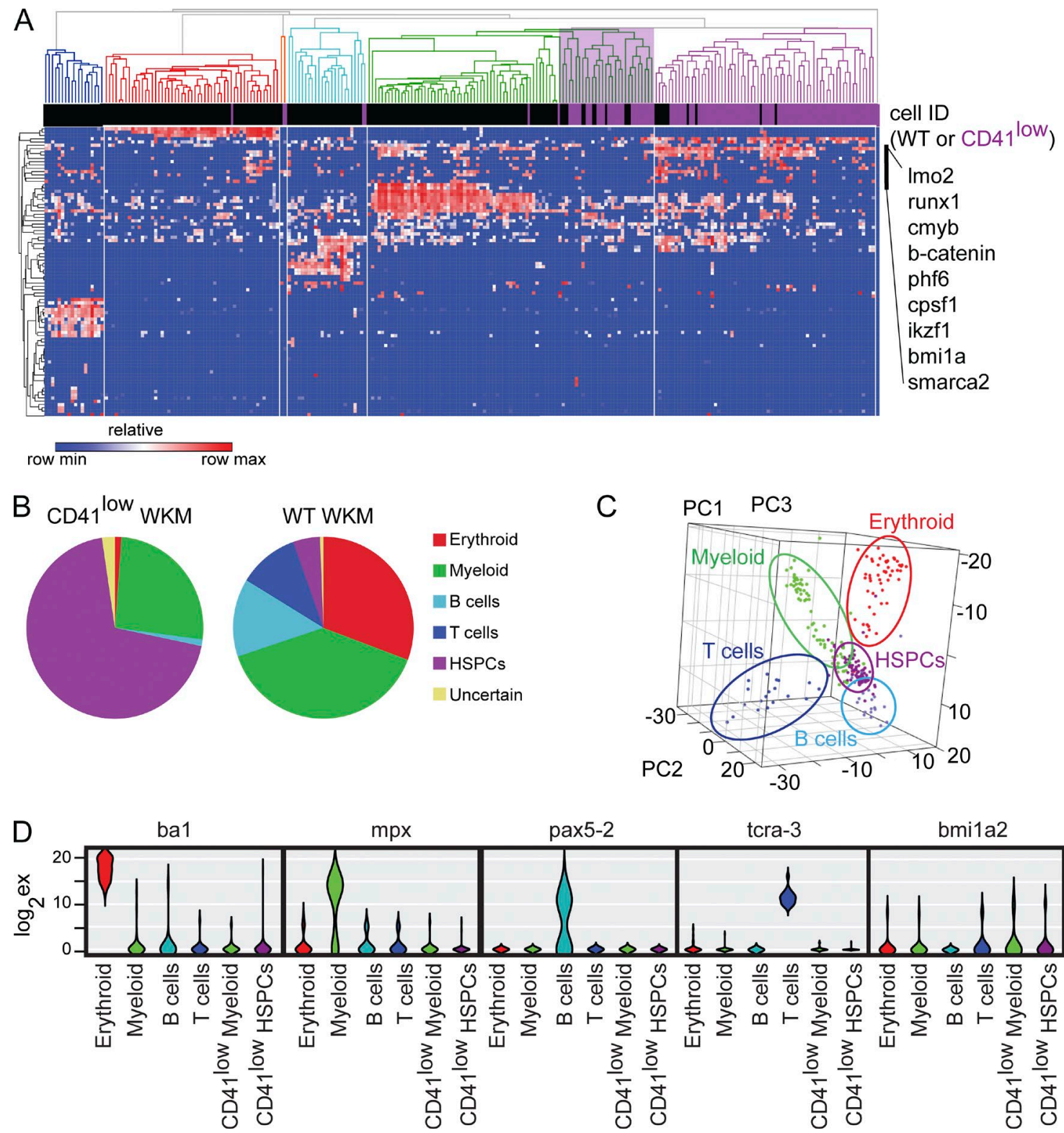

Figure 4. Identification of CD41:GFPlow hematopoietic stem and precursor cells. (A) Unsupervised hierarchical clustering comparing gene expression of unlabeled WKM and $\operatorname{Tg}(C D 41: G F P)^{\text {low }}$ cells. Six major lineages were identified including erythroid (red), myeloid (green), B cells (light blue), T cells (dark blue), myeloid-associated CD41:GFP' cells (denoted by light purple shading in dendogram), and HSPCs (purple). The cell identity of each sorted cell is shown as rectangles immediately below the dendograms, unlabeled WKM (black), and Tg(CD41:GFP) low (purple). $n=166$ WT WKM cells (combined from two animals) and $n=85$ CD41:GFPlow WKM cells from a single animal. (B) Pie charts showing proportion of blood lineages in $\operatorname{Tg}(C D 41$ :GFP) low cells when compared with unlabeled WKM cells. (C) Principal component analysis of unlabeled WKM and Tg(CD41:GFP) low cells. (D) Violin plots show the distribution of gene expression of single cells. Cells types were assigned based on hierarchical clustering and assessed for transcript expression of well-known blood cell lineage genes.

rag2-deficient mice have an expansion of NK cells (Shinkai et al., 1992; Wang et al., 1996), we reasoned that rag2 $2^{E 450 f s}$ mutant zebrafish might have elevated numbers of cytotoxic innate immune cells. NK-lysins are ancient antimicrobial proteins that are functionally similar to Granulysin, a protein produced by both CTLs and NK cells in mammals (Andersson et al., 1995; Peña et al., 1997). Of the four NK-lysin genes in zebrafish, $N K$-lysin 4 (nkl.4) is up-regulated after response to viral infection, suggesting $n k l .4$ could be a marker for cytotoxic T/NK cells in the zebrafish (Pereiro et al., 2015). Thus, nkl.4 was included in our panel of 48 experimental genes. After transcriptional profiling of single cells from the marrow of rag2 $2^{E 450 f}$ mutant fish, we found a remarkable 10-fold expansion of $n k 1.4^{+}$cells, now comprising $6 \%$ of mutant WKM (Fig. 5 B and Fig. S3; P = 0.0081, Fisher's exact test). nkl. $4^{+}$ cells expressed tcra, tcrbC1, il7r, and lck (Fig. 5 C), suggesting 

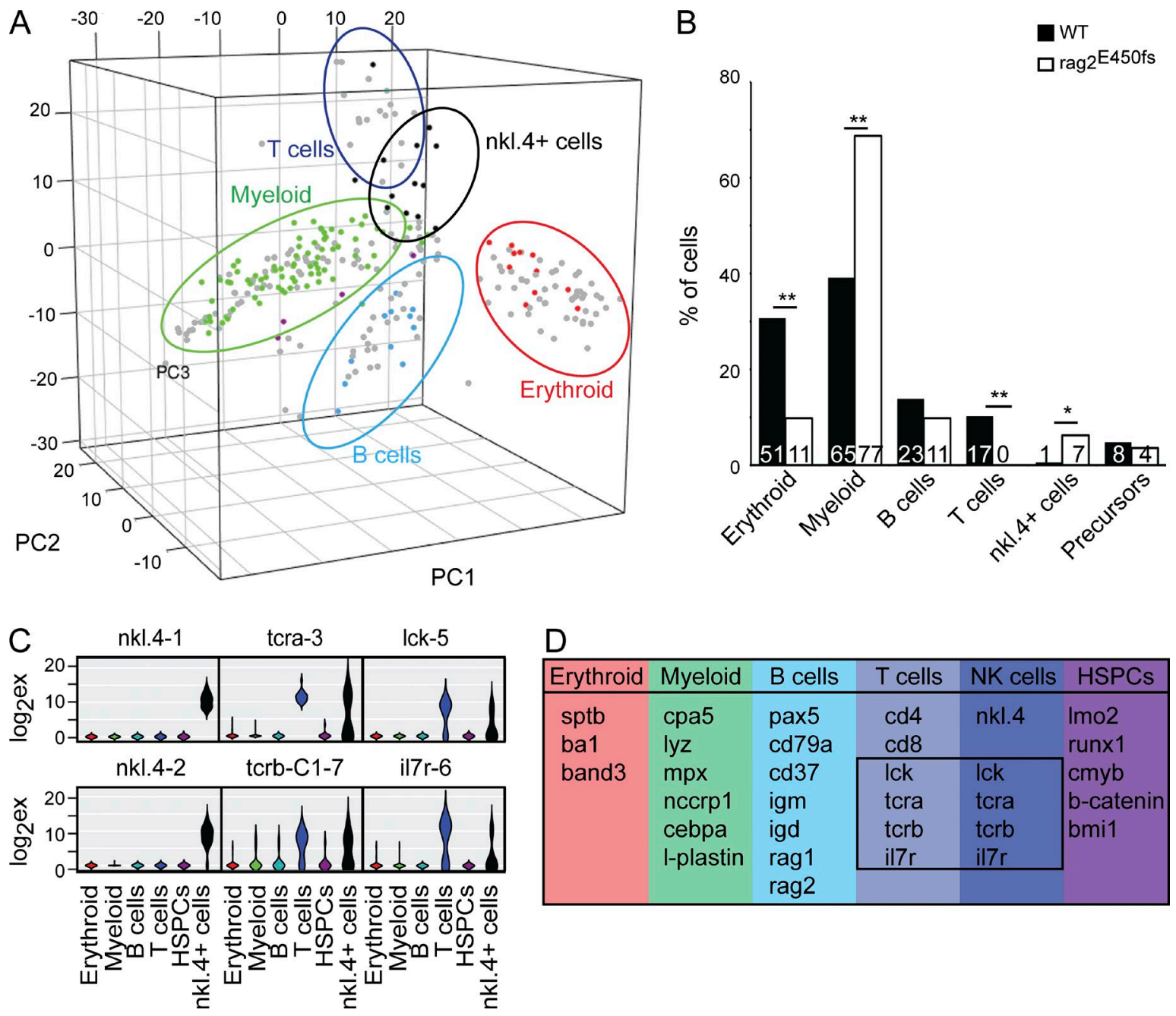

Figure 5. $\quad r a g 2^{E 450 f 5}$ mutant zebrafish have reduced T cells and expanded myeloid and $\boldsymbol{n k l} \cdot \mathbf{4}^{+}$cells. (A) Principal component analysis showing loss of T cells from the WKM of rag2 $2^{\text {E450fs }}$ mutant zebrafish and expansion of $n k 1.4^{+}$cells (black). WT and rag2 $2^{E 450 f 5}$ WKM were included in PCA. For visualization, cells from rag2 ${ }^{E 40 f 5}$ WKM are shown in color, and WT WKM cells are greyed circles. (B) Quantification of blood cell types from the marrow of WT and rag $2^{E 450 f 5}$ mutant zebrafish. Counts were based on single-cell PCR gene expression and assignments based on hierarchical clustering defined in Fig. 3. ${ }^{*}, P=0.0081 ;{ }^{* *}$, $P=0.0001$, by Fisher's exact test. The numbers of cells per lineage are noted within the bar graph. $n=166$ WT WKM cells and $n=112$ rag $2^{E 450 f s}$ WKM cells combined from two animals. (C) Violin plots show the distribution of gene expression in $n k l .4^{+}$cells. (D) Genes expressed within each cell type.

these cells are distinct but related to T cells. Given the lack of other mature lineage marker expression (Fig. S3 B), we posit that these cells define a novel blood cell type and are likely related to cytotoxic T/NK cells. Myeloid cells were also greatly expanded in this model (Fig. 5, A and B; P $=0.0001$, Fisher's exact test), suggesting that compensatory mechanisms are turned on in rag2 $2^{E 50 \text { fs }}$ mutant fish to curb infection. In total, our studies revealed quantitative deficiencies in blood cell subpopulations from mutant animals and discovered new cell types not previously identified in zebrafish.

\section{Analysis of differentiation arrest and reactivation of stem cell genes in T cell acute lymphoblastic leukemia}

T-ALLs are heterogeneous, comprising many molecular subtypes arrested at different stages of $\mathrm{T}$ cell maturation
(Ferrando et al., 2002; Ferrando and Look, 2003; van Grotel et al., 2008). For example, the zebrafish Myc-induced T-ALL model has been previously suggested to mimic a common and aggressive form of human leukemia with cells arrested at the $\mathrm{CD}^{+} / \mathrm{CD}^{+}$cortical thymocyte stage of development (Langenau et al., 2005; Blackburn et al., 2012). Single cells were isolated from normal rag2:dsRed ${ }^{+}$thymocytes and compared with three T-ALLs that had similar latency and high leukemiapropagating cell (LPC) frequency (Blackburn et al., 2014; Fig. 6,A and C; and Table S3).After single-cell transcriptional profiling, rag2: dsRed ${ }^{+}$thymocytes were comprised of $11.7 \%$ double-negative (DN) cells, 53.2\% double-positive (DP) cells, and single-positive $\mathrm{CD}^{+}$or $\mathrm{CD}^{+}$cells $(10.4$ and $24.7 \%$, respectively; Fig. $6 \mathrm{D}$ and Fig. S4). In contrast, $>87 \%$ of T-ALL cells coexpressed both CD4 and CD8, showing 
that leukemias were arrested at the immature double-positive (DP) stage (Fig. $6 \mathrm{D} ; \mathrm{P}=0.0001$, Fisher's exact test).

Principal component analysis also revealed that T-ALLs are molecularly distinct from both normal rag2 :dsRed $d^{+}$thymocytes and lck:GFP $P^{+}$mature T cells (Fig. 6 E). Remarkably, T-ALL cells transcribed genes not normally expressed in thymocytes. WGCNA identified stem cell genes that were specifically found in T-ALLs (Fig. 6 F). For instance, the early $\mathrm{T}$ cell maturation genes rag 1 and gata 3 were highly expressed in a large fraction of T-ALL cells, reflecting the strong developmental arrest at the DP stage (Fig. $6 \mathrm{G}$ ). Leukemias also showed inappropriate activation of $b$-catenin (Fig. $6 \mathrm{G}$ ), reminiscent of recent studies that showed Wnt pathway contributes to LPC self-renewal in T-ALL (Guo et al., 2008; Giambra et al., 2015). bmi1, a well-known driver of self-renewal in both normal and malignant blood (Dik et al., 2005; Hosen et al., 2007; Saudy et al., 2014), was expressed in a subfraction of T-ALL cells, but was not expressed in normal thymocytes (Fig. 6 G; P $=0.0001$, Fisher's exact test). $c m y b$ is required for the proliferation and differentiation of HSPCs (Mucenski et al., 1991; Sandberg et al., 2005). MYB is also required for T-ALL growth and maintenance (Lahortiga et al., 2007; Mansour et al., 2014). cmyb was highly expressed in zebrafish T-ALL cells (Fig. 6 G; P $=0.0001$, Fisher's exact test). In fact, cmyb and bmi1 were coexpressed in $18.4 \%$ of T-ALL cells, but not normal T cells $(n=46$ of $250 \mathrm{~T}$-ALL cells and $n=0$ of 160 normal T cells, $\mathrm{P}=0.0001$, Fisher's exact test). Intriguingly, $\sim 17 \%$ of leukemic cells were LPCs as assessed by limiting dilution cell transplantation (Fig. $6 \mathrm{~A}$ and Table S3). These data suggest that $\mathrm{bmil}^{+} / \mathrm{cmyb} \mathrm{b}^{+} \mathrm{T}$-ALL cells may represent the self-renewing LPCs. Collectively, our results demonstrate that Myc-induced T-ALLs are arrested at immature cortical thymocyte stage and that a minority of tumor cells aberrantly reexpress stem cell genes.

\section{DISCUSSION}

Multiparameter flow cytometry and mass cytometry have richly profiled single-cell heterogeneity in blood and leukemia (Irish et al., 2006; Kotecha et al., 2008; Bendall et al., 2011, 2014; Gibbs et al., 2011; Lacayo et al., 2013; Litjens et al., 2013). Although these approaches have revolutionized how we analyze diversity in hematopoietic cells, they require a large set of validated antibodies specific to a given lineage or cell subtype. Yet, antibody reagents are sorely lacking in zebrafish. More recently, cell heterogeneity has also been defined by differences in gene expression between single cells. Single-cell qPCR using the Fluidigm platform has assessed novel transcriptional networks in blood, $\mathrm{T}$ cell diversity in response to vaccination, and self-renewal programs in AML (Flatz et al., 2011; Guo et al., 2013; Moignard et al., 2013). For instance, Moignard et al. (2013) examined transcription factor expression using single-cell qPCR analysis of mouse hematopoietic cells and uncovered novel gene regulatory networks between gata1, gfi1, and gfi2. Guo et al. (2013) also used single-cell qPCR to assess differentiation hierarchies in normal blood cells and revealed gene expression changes associated with self-renewal in leukemic cells. Our work has optimized a simple qPCR transcriptional profiling approach using the Fluidigm platform to assess heterogeneity in zebrafish blood. This approach is advantageous in that it allows analysis of lineage-restricted genes to define cell states, can detect low-level expressed genes, including transcription factors, and is facile in both its implementation and data analysis. Moreover, using this approach, we have refined gene expression of novel blood cell types and uncovered new biology underlying hematopoiesis in the zebrafish model.

Capitalizing on the power of single-cell qPCR to identify blood cell types within the marrow, we assessed if we could identify quantitative losses of specific cell types in hematopoietic mutant zebrafish. Our single-cell transcriptional analysis uncovered that rag $2^{\text {E450fs }}$ mutant zebrafish lack $\mathrm{T}$ cells but have a largely intact $\mathrm{B}$ repertoire, in agreement with previous work (Tang et al., 2014). The rag2 $2^{\text {E450fs }}$ mutant also had a significant increase in myeloid cells, similar to that suggested for rag1 mutant zebrafish (Petrie-Hanson et al., 2009) and contain a previously undescribed cell type that express nkl.4. NK-lysins are functionally similar to Granulysin, which is produced by CTLs and natural killer (NK) cells in mammals (Andersson et al., 1995; Peña et al., 1997). rag2 deficiency in mice leads to NK cell expansion as a result of the lack of inhibition by normal $\mathrm{T}$ cells (Shinkai et al., 1992; Wang et al., 1996), suggesting the expansion of $n k 1.4^{+}$cells observed in rag2 ${ }^{E 450 \text { fs }}$ zebrafish could also represent cytotoxic T/NK cells. Collectively, our single-cell qPCR approach provides a robust platform to quantify blood cell deficiencies in mutant zebrafish, bypassing the need for transcriptional analysis of bulk marrow and inference of cell losses based on bulk RNA expression changes (Tang et al., 2014; Pereiro et al., 2015).

Our work also characterized rare CD41:GFP ${ }^{\text {low }}$ HSPCs in the normal WKM. In agreement with findings in the zebrafish embryo, adult HSPCs express $1 \mathrm{mo} 2$, runx 1 , and cmyb (Burns et al.,2005; Bertrand et al., 2008). Other stem cell genes are likely further restricted to less differentiated precursors, or even to hematopoietic stem cells (HSCs). For instance, bmi1, though expressed in mouse HSCs (Hosen et al., 2007), is not commonly expressed in zebrafish CD41:GFP ${ }^{\text {low }}$ HSPCs, reflecting the rarity of HSCs even within the progenitor compartment. Single-cell qPCR also captured additional heterogeneity within $C D 41: G F P^{\text {low }}$ cells, identifying a group of transitioning HSPCs that failed to express cmyb, runx1, or other lineage-restricted genes. Heterogeneity within CD41:GFP ${ }^{\text {low }}$ cells is expected given that imaging and FACS experiments have demonstrated variable coexpression of $C D 41: G F P^{\text {low }}$ cells with other progenitor markers (Bertrand et al., 2008; Tamplin et al., 2015).

Our single-cell transcriptional platform also enabled analysis of differentiation states and reinitiation of stem cell programs in a subset of leukemia cells. For example, we found that Myc-induced T-ALL cells were arrested at the immature CD4/CD8 DP stage. Similarly, zebrafish T-ALLs showed ab- 

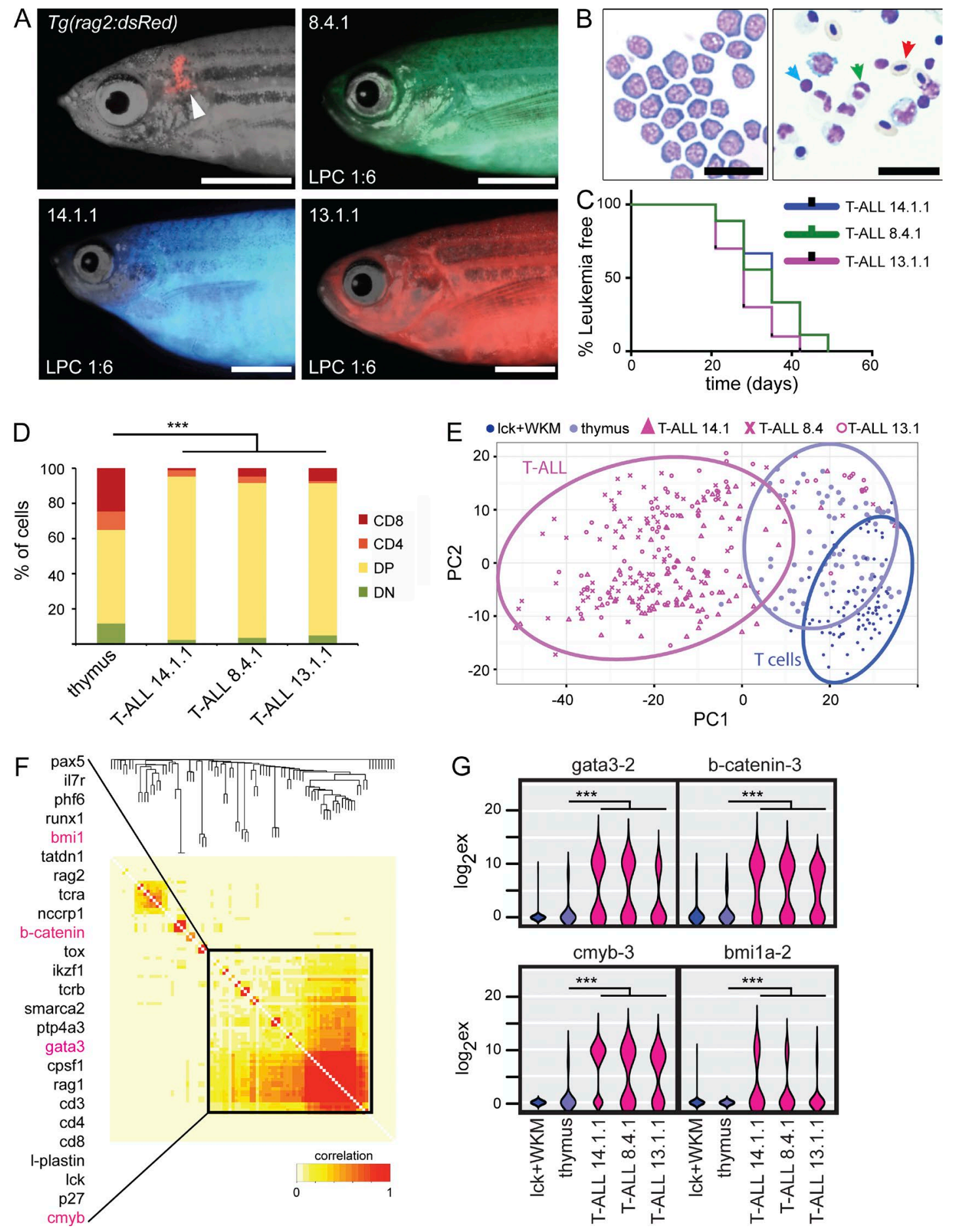

Figure 6. Zebrafish Myc-induced T-ALLs are arrested at the $C D 4^{+} / \mathrm{CD}^{+}$cortical thymocyte stage and reexpress stem cell genes. (A) Merged bright field and fluorescent images of $\mathrm{Tg}(\mathrm{rag} 2 \mathrm{dsRed}$ ) zebrafish (top left) or fluorescent leukemic fish. LPC frequency for each individual T-ALL is denoted in bottom left corner of each image, and clone name is denoted in the top left corner. The white arrowhead designates thymus. Bars, 2.5 mm. (B) May-Grunwald staining of representative T-ALL cells (left) and normal WKM (right; red blood cell, red arrow; myeloid cell, green arrow, and lymphocyte, blue arrow). Bars, $25 \mu \mathrm{m}$. (C) Kaplan-Meier analysis of leukemia onset in transplanted zebrafish. Number designations correspond to leukemias described by Blackburn et al. (2014). (D) Percentage of T cells that express CD4 and CD8 in normal rag2:dsRed thymic T cells and fluorescent-labeled T-ALLs. ${ }^{* *}, P=0.0001, b y$ Fisher's exact test. (E) Principal component analysis identified three distinct clusters of cells that include the following: mature T cells (Tg(lck:GFP) dark blue, $n=83$ cells), thymocytes (Tg(rag2:dsRed) light blue, $n=77$ cells from a single animal), and T-ALLs (pink, $n=250$ cells, combined from three independent leukemias). (F) WGCNA of T-ALLs revealed that stem cell genes are reexpressed in T-ALLs and expressed together. Each row and column corresponds to a specific gene 
normally high expression of genes that affect differentiation in normal hematopoiesis, including cmyb and gata3. These transcription factors are highly expressed in a large cohort of T-ALL patient samples (Minegishi et al., 1997; Clappier et al., 2007; Lahortiga et al., 2007). Intriguingly, knockdown of $M Y B$ causes human T-ALL cells to partially differentiate (Lahortiga et al., 2007), suggesting the high expression of $c m y b$ could contribute to the maintenance of zebrafish T-ALL maturation arrest. BMI1 confers self-renewal properties to a variety of solid and hematological tumors, including multiple subtypes of T-ALL (Jacobs et al., 1999; Lessard and Sauvageau, 2003; Sayitoğlu et al., 2012; Saudy et al., 2014). Cells that expressed both bmi1 and cmyb comprised $18.4 \%$ of zebrafish T-ALL cells and correlated well with LPC frequency as assessed by limiting dilution cell transplantation, raising the interesting possibility that these genes define LPCs in the zebrafish model.The expression pattern of stem cell genes, such as bmi1 and cmyb, in a minority of tumor cells demonstrates the power of single-cell analysis in studying rare cell subtypes and provides new testable hypotheses about leukemia LPCs.

Looking to the future, we envision that expanded primer sets will be developed for use with the Fluidigm platform, allowing further subclassification of blood and leukemia cell types. Importantly, we also anticipate that future studies will use single-cell RNA sequencing to investigate blood cell heterogeneity. RNASeq has become a powerful technology to assess single-cell transcriptomes and identified novel gene networks in embryonic stem cells, retinal cells, blood and development (Shalek et al., 2013; Fan et al., 2015; Klein et al., 2015; Macosko et al., 2015; Satija et al., 2015; Wilson et al., 2015). Because single-cell RNA sequencing often only captures transcriptional changes confined to highly expressed genes, analysis of low expressed genes including transcription factors, as assessed in our qPCR analysis, is often incomplete. Thus, we believe that combining our qPCR profiling approach with RNA sequencing will likely permit anchoring of large-scale, single-cell RNASeq data. This approach is similar to those pioneered in mouse and human, where antibody labeling and FACS delineate distinct blood cell populations, which can then be further refined by RNA sequencing approaches. For example, Wilson et al. (2015) used FACS to enrich for mouse HSPCs, which were then assessed by RNASeq to identify previously unappreciated heterogeneity in this cell population and to discover new gene networks that affect self-renewal. Although qPCR profiling will complement RNASeq approaches, it cannot replace FACS to functionally analyze single cells caused by the destructive nature of RNA extraction. Our approach provides a robust assay to define a wide range of blood cell types after transcriptional profiling by qPCR, obviating the need to identify single-cell heterogeneity using cell surface antibodies and FACS.
In total, our work provides the first analysis of gene expression at the single-cell level in zebrafish blood development and has identified novel cell types not previously defined in the zebrafish model. We have demonstrated the utility of single-cell qPCR in zebrafish as an accessible and facile tool to study heterogeneous blood cell populations.

\section{MATERIALS AND METHODS}

Zebrafish. All experiments were completed with IACUC approval from the Massachusetts General Hospital (2011N000127).

Experiments used WT AB strain zebrafish, rag2 $2^{\text {E450fs }}$ mutant fish (Tang et al., 2014), and the following transgenic lines: $\operatorname{Tg}$ (gata1:dsRed) (Traver et al., 2003), $\operatorname{Tg}(m p x: G F P)$ (Mathias et al., 2006), Tg(rag2:dsRed) (Ma et al., 2012), $T g$ (rag2:GFP) (Langenau et al., 2003), Tg(lck:GFP) (Langenau et al., 2004), and $\operatorname{Tg}(C D 41: G F P)$ (Lin et al., 2005). Leukemic fish were created by implantation of monoclonal, fluorescent T-ALLs into syngeneic CG1 recipient animals, as previously described $\left(10^{5}\right.$ cells/fish; Blackburn et al., 2014). KaplanMeier analysis was completed on engrafted animals, and LPC frequency was evaluated at the time of single-cell sorting using the Extreme Limiting Dilution Analysis algorithm as previously described (Smith et al., 2010).

Sample preparation and isolation of single cells by FACS. WKM and thymocytes were isolated from 3-6-mo-old fish, placed in $5 \%$ FBS $/ 1 \times$ PBS, triturated by pipet, and filtered through a $35-\mu \mathrm{m}$ cell strainer. T-ALL were harvested by dicing diseased animals in 5\% FBS/1xPBS and filtering through $40-\mu \mathrm{m}$ cell strainer (Falcon 352340), as previously described (Smith et al., 2010; Blackburn et al., 2012). For WT and rag $2^{\text {E450fs }}$ mutant WKM, cells were isolated from two animals, sorted independently, and then combined for analysis.

All samples were single-cell sorted in the presence of cell viability stain (DAPI or PI) using the FACSAria Fusion Cell Sorter (BD). Doublets were gated out based on forward-scatter area compared with forward-scatter height. Cell purity was assessed by sorting and reanalysis, showing enrichment of fluorescent reporters to $>92 \%$ and viability $>95 \%$. Single cells were sorted into 96 -well plates, with each well containing $5 \mu \mathrm{l}$ of lysis buffer $(10 \mathrm{ml}$ master mix was made combining $9.5 \mathrm{ml}$ DNA Suspension Buffer [TEKnova T0221], $50 \mu \mathrm{l}$ $20 \mathrm{U} / \mu \mathrm{l}$ SUPERase-in [Ambion AM2696], and $500 \mu \mathrm{l} 10 \%$ NP-40 [AppliChem A2239]). Unlabeled WKM samples were index sorted. Plates were centrifuged, frozen on dry ice, and stored at $-80^{\circ} \mathrm{C}$ until further use.

Primer optimization. Selected genes were identified using NCBI, Ensembl, and ZFIN databases. PCR primers spanned

primer set. The heat map represents WCGNA adjacency dissimilarity values in the range between 0 (low topological overlap, light yellow) and 1 (high topological overlap, dark red). Red lettering denotes genes shown in G. (G) Violin plots show the distribution of transcript expression for genes involved in T cell differentiation and stem cells. ${ }^{* *}, P=0.0001$, by Fisher's exact test. 
introns when possible, were restricted to regions that were common to all REFseq transcripts, and were verified for specificity by PrimerBLAST (Ye et al., 2012). Primer sequences are listed in Table S1.

Primers were tested on the BioMark (Fluidigm; and also ABI7500) using bulk cDNA, as well as single cells. Varying amounts of bulk cDNA, no room temperature samples, and water were used as controls. Bulk cDNA from embryos (single cell, 24 hpf, 5 dpf embryos), WT WKM, several T-ALL clones, peripheral blood, and thymus was used. Primers were ordered in plates $(200 \mu \mathrm{l}$ well volume, $25 \mathrm{nM}$ synthesis scale, desalted purification, TE buffer, ambient ship format, normalized concentration to $100 \mu \mathrm{M}$ ) obtained from Invitrogen. Outer primers were prepared as follows: $100 \mu \mathrm{M}$ forward and $100 \mu \mathrm{M}$ reverse were mixed, and then $3.3 \mu \mathrm{l}$ of each primer pair were pipeted into Eppendorf tube, $99.1 \mu \mathrm{l}$ DNA suspension buffer (TEKnova T0221), such that the STA Outer Primer mix has each primer at a concentration of $166.6 \mathrm{nM}$. Inner primers were as follows for $20 \mu \mathrm{l}$ of $5 \mu \mathrm{M}$ stock: $10 \mu \mathrm{l}$ 2X Assay Loading Reagent (Fluidigm PN 85000736), $8 \mu \mathrm{l} 1 \mathrm{X}$ DNA Suspension Buffer (TEKNova PNT0211), $1 \mu$ forward primer $(100 \mu \mathrm{M})$, and $1 \mu \mathrm{l}$ reverse primer $(100 \mu \mathrm{M})$.

Single-cell qPCR using the BioMark HD. Plates were thawed on ice and heated at $65^{\circ} \mathrm{C}$ for $90 \mathrm{s.} 1 \mu \mathrm{l}$ of Reverse Transcription Mix (100-6299; Fluidigm) was added to each well and then placed into a thermocycler for $25^{\circ} \mathrm{C}, 5 \mathrm{~min} ; 42^{\circ} \mathrm{C}, 30$ $\mathrm{min}$; and $85^{\circ} \mathrm{C}, 5 \mathrm{~min}$. Next, a preamplification step was completed using gene-specific primers (Table S1, outer primers). To each $6 \mu \mathrm{l}$ cDNA RT reaction, $1 \mu \mathrm{l}$ 10X PreAmp Master Mix (100-5581; Fluidigm) and $3 \mu 1166.6$ nM specific target amplification (STA) outer primer mix was added. Plates were placed into the thermocycler for $95^{\circ} \mathrm{C}, 5 \mathrm{~min}$ and 20 cycles of $96^{\circ} \mathrm{C}, 5 \mathrm{~s}$ and $60^{\circ} \mathrm{C}, 6 \mathrm{~min}$. Unincorporated primers were removed by exonuclease treatment (for each $10 \mu$ preamplification reaction, $0.8 \mu \mathrm{l} 20 \mathrm{U} / \mu \mathrm{l}$ exonuclease I [NEB M0293L], $0.4 \mu \mathrm{l}$ 10X Exonuclease I Buffer, $\left.2.8 \mu \mathrm{H}_{2} \mathrm{O}\right)$ and incubating at $37^{\circ} \mathrm{C}$ for $30 \mathrm{~min}$, and then $80^{\circ} \mathrm{C}$ for $15 \mathrm{~min}$. Samples were then diluted by addition of $36 \mu \mathrm{l}$ of $1 \mathrm{xTE}$. Each well now contained $50 \mu \mathrm{l}$ of preamplified cDNA that was ready for $\mathrm{qPCR}$ using the BioMark HD.

Samples were prepared for qPCR by combining $3 \mu$ of sample with $3.5 \mu \mathrm{l} 2 \mathrm{X}$ SSo Fast EvaGreen Supermix with low ROX (172-5212; Bio-Rad Laboratories), $0.35 \mu$ l 20X DNA Binding Dye Sample Loading Reagent (100-7609; Fluidigm), and $0.15 \mu \mathrm{H}_{2} \mathrm{O} .5 \mu \mathrm{M}$ inner primer mix was prepared by combining $2.5 \mu \mathrm{l}$ 2X Assay Loading Reagent (85000736; Fluidigm), $2 \mu \mathrm{l}$ 1X DNA Suspension Buffer (TEKNova T0211), $0.25 \mu \mathrm{l}$ forward primer (Invitrogen $100 \mu \mathrm{M}$ ), $0.25 \mu \mathrm{l}$ reverse primer (Invitrogen $100 \mu \mathrm{M}$ ) for each primer. After priming the 96.96 Dynamic Array Chip for Gene Expression or integrated fluidic circuit (IFC; BMK-M-96.96; Fluidigm), $5 \mu \mathrm{l}$ primers and $5 \mu \mathrm{l}$ samples were loaded onto IFC and mixed in the Fluidigm IFC controller HX. IFC was then loaded into the BioMark HD following manufacturer's protocol.Thermal cycling was completed using protocol GE $96 \times 96$ PCR melt v2.pcl $\left(2,400 \mathrm{~s}\right.$ at $70^{\circ} \mathrm{C}, 30 \mathrm{~s}$ at $60^{\circ} \mathrm{C}, 60 \mathrm{~s}$ at $95^{\circ} \mathrm{C}, 30 \mathrm{cycles}$ of $5 \mathrm{~s}$ at $96^{\circ} \mathrm{C}, 20 \mathrm{~s}$ at $60^{\circ} \mathrm{C}$, melting curve $60-95^{\circ} \mathrm{C}, 1^{\circ} \mathrm{C} / 3 \mathrm{~s}$ ).

Statistical analysis and display of single-cell data. $\mathrm{C}_{t} \mathrm{~s}$ were recovered from the BioMark HD. The quality threshold was set to 0.65 and a linear derivative as baseline correction was used. Limit of detection was set to the $\mathrm{C}_{\mathrm{t}}$ of 28 ; $\mathrm{C}_{\mathrm{t}}$ s for qPCR reactions that failed the quality threshold were converted to 28. $\mathrm{C}_{\mathrm{t}} \mathrm{s}$ were converted to $\log _{2}$ expression by subtracting $\mathrm{C}_{\mathrm{t}} \mathrm{s}$ from 28. Sample wells that failed to express housekeeping genes ( $E F 1 \alpha$ and $\beta$-actin) or other lineage-specific markers were deemed to lack a cell and were eliminated from further analysis.

Unsupervised hierarchical clustering used Pearson rank coefficient and was completed using GENE-E package (Broad Institute). All samples were included in a single large hierarchical clustering heat map. The principal component analysis (PCA) was conducted using pcromp method in R. Loading plots for the first three principal components were used to visualize the relative positioning of samples in the multidimensional space of gene expression. Correlation network analysis was performed using WGCNA package (Langfelder and Horvath, 2008; Saadatpour et al., 2014). Expression values were converted to an adjacency matrix constructed from Pearson correlation coefficients as follows: power adjacency function, $a_{\mathrm{ij}}=\left|r\left(x_{\mathrm{i}}, x_{\mathrm{j}}\right)\right|^{\alpha}$ to define the connection strength between pairs of genes $x_{i}$ and $x_{j}$. Soft power threshold $(\alpha)$ is applied to network construction to emphasize high correlations and minimize low correlations. Based on the adjacency matrix, topological overlap matrix (TOM) and its modules were calculated and used to construct the dendogram of primers. The TOM was plotted as a heatmap. To obtain more informative topology, power threshold was modified to 4 for WT WKM (Fig. 1), and 3 for T-ALLs (Fig. 6). For confirmation, hierarchical clustering, three-dimensional PCA, one-way ANOVA, violin plots, and correlation values were also generated using the SINGuLAR $\mathrm{R}$ package, with limit of detection set to the $\mathrm{C}_{t}$ of 28 .

Fisher's exact test was performed on cell numbers for Figs. 5 B, 6 D, and 6 G. For Fig. 6 G, Fisher's exact test was performed on cell numbers by establishing cut-off of $\log _{2}$ expression of five to designate high- or low-expressing cells. Cells from the three T-ALLs were grouped together for Fig. 6 (D and $G$ ). Table 2 shows the order of genes and primer pairs used to generate heat maps shown in Figs. 1, 2, and 4 and Figs. S2 and S3.

Online supplemental material. Fig. S1 shows the complete heat map with primer identifiers for the Weighted Gene CoExpression Analysis shown in Fig. 1 B. Fig. S2 shows unsupervised hierarchical clustering of cells from unlabeled WKM and transgenic reporter lines. Fig. S3 shows unsupervised hierarchical clustering of WT and rag2 $2^{\text {E450fs }}$ WKM. Fig. S4 shows thymocyte maturation states as assessed by single-cell qPCR. Table S1 is a list of primer sequences for 
outer preamplification and inner qPCR reactions. Table S2 lists the primer order and complete gene name for heat maps depicted in Figs. 1, 2, 4 and Figs. S2 and S3. Table S3 shows limiting dilution cell transplantation analysis and LPC frequency for the Myc-induced T-ALLs shown in Fig. 6. Online supplemental material is available at http://www.jem .org/cgi/content/full/jem.20152013/DC1.

\section{ACKNOWLEDGMENTS}

We thank Daniel Haber, David Miyamoto, and Katherine Broderick for technical assistance and use of the BioMark HD. We would like to acknowledge the technical advice and assistance of Ken Livak and Chris Simollardes of Fluidigm for help in optimizing qPCR protocols. We thank Damon Magnuski, Michka Sharpe, David Adamovich, and Liz Millett for statistical analysis and thoughtful review of this manuscript.

This work was supported by Alex's Lemonade Stand Foundation (D.M. Langenau), The Live Like Bella Foundation for Childhood Cancer (D.M. Langenau), American Cancer Society (D.M. Langenau), the Massachusetts General Hospital (MGH) Howard Goodman Fellowship (D.M. Langenau), and National Institutes of Health (NIH) grant R240D016761. F.E. Moore is supported by NIH grant 5F32DK098875-03. Flow cytometry and sorting services were supported by MGH Pathology CNY Flow Cytometry Core shared instrumentation grant 1S10RR023440-01A.

The authors declare no competing financial interests.

\section{Submitted: 28 December 2015}

Accepted: 17 March 2016

\section{REFERENCES}

Amir el, A.D., K.L. Davis, M.D. Tadmor, E.F. Simonds, J.H. Levine, S.C Bendall, D.K. Shenfeld, S. Krishnaswamy, G.P. Nolan, and D. Pe'er. 2013 viSNE enables visualization of high dimensional single-cell data and reveals phenotypic heterogeneity of leukemia. Nat. Biotechnol. 31:545552. http://dx.doi.org/10.1038/nbt.2594

Andersson, M., H. Gunne, B. Agerberth, A. Boman, T. Bergman, R. Sillard, H. Jörnvall,V. Mutt, B. Olsson, H. Wigzell, et al. 1995. NK-lysin, a novel effector peptide of cytotoxic T and NK cells. Structure and cDNA cloning of the porcine form, induction by interleukin 2, antibacterial and antitumour activity. EMBO J. 14:1615-1625.

Bendall, S.C., E.F. Simonds, P. Qiu, A.D. Amir el, P.O. Krutzik, R. Finck, R.V. Bruggner, R. Melamed, A. Trejo, O.I. Ornatsky, et al. 2011. Singlecell mass cytometry of differential immune and drug responses across a human hematopoietic continuum. Science. 332:687-696. http://dx.doi .org/10.1126/science.1198704

Bendall, S.C., K.L. Davis, A.D. Amir, M.D. Tadmor, E.F. Simonds, T.J. Chen, D.K. Shenfeld, G.P. Nolan, and D. Pe'er. 2014. Single-cell trajectory detection uncovers progression and regulatory coordination in human $\mathrm{B}$ cell development. Cell. 157:714-725. http://dx.doi.org/10.1016/j.cell 2014.04.005

Bertrand, J.Y., A.D. Kim, S. Teng, and D. Traver. 2008. CD41+ cmyb+ precursors colonize the zebrafish pronephros by a novel migration route to initiate adult hematopoiesis. Development. 135:1853-1862. http://dx .doi.org/10.1242/dev.015297

Blackburn, J.S., S. Liu, D.M. Raiser, S.A. Martinez, H. Feng, N.D. Meeker, J. Gentry, D. Neuberg, A.T. Look, S. Ramaswamy, et al. 2012. Notch signaling expands a pre-malignant pool of T-cell acute lymphoblastic leukemia clones without affecting leukemia-propagating cell frequency. Lenkemia. 26:2069-2078. http://dx.doi.org/10.1038/leu.2012.116

Blackburn, J.S., S. Liu, J.L. Wilder, K.P. Dobrinski, R. Lobbardi, F.E. Moore, S.A. Martinez, E.Y. Chen, C. Lee, and D.M. Langenau. 2014. Clonal evolution enhances leukemia-propagating cell frequency in $\mathrm{T}$ cell acute lymphoblastic leukemia through Akt/mTORC1 pathway activation. Cancer Cell. 25:366-378. http://dx.doi.org/10.1016/j.ccr.2014.01.032
Burns, C.E., D. Traver, E. Mayhall, J.L. Shepard, and L.I. Zon. 2005. Hematopoietic stem cell fate is established by the Notch-Runx pathway. Genes Dev. 19:2331-2342. http://dx.doi.org/10.1101/gad.1337005

Chen, J., C. Jette, J.P. Kanki, J.C. Aster, A.T. Look, and J.D. Griffin. 2007. NOTCH1-induced T-cell leukemia in transgenic zebrafish. Lenkemia. 21:462-471. http://dx.doi.org/10.1038/sj.leu.2404546

Clappier, E., W. Cuccuini, A. Kalota, A. Crinquette, J.M. Cayuela, W.A. Dik, A.W. Langerak, B. Montpellier, B. Nadel, P. Walrafen, et al. 2007. The $\mathrm{C}-\mathrm{MYB}$ locus is involved in chromosomal translocation and genomic duplications in human T-cell acute leukemia (T-ALL), the translocation defining a new T-ALL subtype in very young children. Blood. 110:12511261. http://dx.doi.org/10.1182/blood-2006-12-064683

Cutler, C., P. Multani, D. Robbins, H.T. Kim, T. Le, J. Hoggatt, L.M. Pelus, C. Desponts, Y.B. Chen, B. Rezner, et al. 2013. Prostaglandin-modulated umbilical cord blood hematopoietic stem cell transplantation. Blood. 122:3074-3081. http://dx.doi.org/10.1182/blood-2013-05-503177

Dik, W.A., W. Brahim, C. Braun, V. Asnafi, N. Dastugue, O.A. Bernard, J.J. van Dongen, A.W. Langerak, E.A. Macintyre, and E. Delabesse. 2005. CALM-AF10+ T-ALL expression profiles are characterized by overexpression of HOXA and BMI1 oncogenes. Leukemia. 19:19481957. http://dx.doi.org/10.1038/sj.leu.2403891

Donovan, A., A. Brownlie, Y. Zhou, J. Shepard, S.J. Pratt, J. Moynihan, B.H Paw, A. Drejer, B. Barut, A. Zapata, et al. 2000. Positional cloning of zebrafish ferroportin1 identifies a conserved vertebrate iron exporter. Nature. 403:776-781. http://dx.doi.org/10.1038/35001596

Fan, H.C., G.K. Fu, and S.P. Fodor. 2015. Expression profiling. Combinatorial labeling of single cells for gene expression cytometry. Science. 347:1258367. http://dx.doi.org/10.1126/science.1258367

Fathman, J.W., D. Bhattacharya, M.A. Inlay, J. Seita, H. Karsunky, and I.L. Weissman. 2011. Identification of the earliest natural killer cellcommitted progenitor in murine bone marrow. Blood. 118:5439-5447. http://dx.doi.org/10.1182/blood-2011-04-348912

Feng, H., D.M. Langenau, J.A. Madge, A. Quinkertz, A. Gutierrez, D.S Neuberg,J.P. Kanki, and A.T. Look. 2007. Heat-shock induction of T-cell lymphoma/leukaemia in conditional Cre/lox-regulated transgenic zebrafish. Br. J. Haematol. 138:169-175. http://dx.doi.org/10.1111/j .1365-2141.2007.06625.x

Ferrando, A.A., and A.T. Look. 2003. Gene expression profiling in T-cell acute lymphoblastic leukemia. Semin. Hematol. 40:274-280. http://dx .doi.org/10.1016/S0037-1963(03)00195-1

Ferrando, A.A., D.S. Neuberg, J. Staunton, M.L. Loh, C. Huard, S.C. Raimondi, F.G. Behm, C.H. Pui, J.R. Downing, D.G. Gilliland, et al. 2002. Gene expression signatures define novel oncogenic pathways in T cell acute lymphoblastic leukemia. Cancer Cell. 1:75-87. http://dx.doi .org/10.1016/S1535-6108(02)00018-1

Flatz, L., R. Roychoudhuri, M. Honda, A. Filali-Mouhim, J.P. Goulet, N Kettaf, M. Lin, M. Roederer, E.K. Haddad, R.P. Sékaly, and G.J. Nabel. 2011. Single-cell gene-expression profiling reveals qualitatively distinct CD8 T cells elicited by different gene-based vaccines. Proc. Natl.Acad. Sci. USA. 108:5724-5729. http://dx.doi.org/10.1073/pnas.1013084108

Frazer, J.K., N.D. Meeker, L. Rudner, D.F. Bradley, A.C. Smith, B. Demarest, D. Joshi, E.E. Locke, S.A. Hutchinson, S. Tripp, et al. 2009. Heritable T-cell malignancy models established in a zebrafish phenotypic screen. Leukemia. 23:1825-1835. http://dx.doi.org/10.1038/leu.2009.116

Giambra, V., C.E. Jenkins, S.H. Lam, C. Hoofd, M. Belmonte, X. Wang, S. Gusscott, D. Gracias, and A.P.Weng. 2015. Leukemia stem cells in T-ALL require active Hif1 $\alpha$ and Wnt signaling. Blood. 125:3917-3927. http:// dx.doi.org/10.1182/blood-2014-10-609370

Gibbs, K.D. Jr., P.M. Gilbert, K. Sachs, F. Zhao, H.M. Blau, I.L. Weissman, G.P. Nolan, and R. Majeti. 2011. Single-cell phospho-specific flow cytometric analysis demonstrates biochemical and functional heterogeneity in human hematopoietic stem and progenitor compartments. Blood. 117:4226-4233. http://dx.doi.org/10.1182/blood-2010-07-298232 
Goessling, W., R.S. Allen, X. Guan, P. Jin, N. Uchida, M. Dovey, J.M. Harris, M.E. Metzger, A.C. Bonifacino, D. Stroncek, et al. 2011. Prostaglandin E2 enhances human cord blood stem cell xenotransplants and shows longterm safety in preclinical nonhuman primate transplant models. Cell Stem Cell. 8:445-458. http://dx.doi.org/10.1016/j.stem.2011.02.003

Guo, G., S. Luc, E. Marco, T.W. Lin, C. Peng, M.A. Kerenyi, S. Beyaz, W. Kim, J. Xu, P.P. Das, et al. 2013. Mapping cellular hierarchy by single-cell analysis of the cell surface repertoire. Cell Stem Cell. 13:492-505. http://dx.doi .org/10.1016/j.stem.2013.07.017

Guo, W., J.L. Lasky, C.J. Chang, S. Mosessian, X. Lewis, Y. Xiao, J.E. Yeh, J.Y Chen, M.L. Iruela-Arispe, M. Varella-Garcia, and H. Wu. 2008. Multigenetic events collaboratively contribute to Pten-null leukaemia stemcell formation. Nature. 453:529-533. http://dx.doi.org/10.1038/ nature06933

Gutierrez, A., R. Grebliunaite, H. Feng, E. Kozakewich, S. Zhu, F. Guo, E. Payne, M. Mansour, S.E. Dahlberg, D.S. Neuberg, et al. 2011. Pten mediates Myc oncogene dependence in a conditional zebrafish model of T cell acute lymphoblastic leukemia. J. Exp. Med. 208:1595-1603. http ://dx.doi.org/10.1084/jem.20101691

Gutierrez, A., L. Pan, R.W. Groen, F. Baleydier, A. Kentsis, J. Marineau, R. Grebliunaite, E. Kozakewich, C. Reed, F. Pflumio, et al. 2014 Phenothiazines induce PP2A-mediated apoptosis in $\mathrm{T}$ cell acute lymphoblastic leukemia. J. Clin. Invest. 124:644-655. http://dx.doi.org /10.1172/JCI65093

Hosen, N., T.Yamane, M. Muijtjens, K. Pham, M.F. Clarke, and I.L. Weissman. 2007. Bmi-1-green fluorescent protein-knock-in mice reveal the dynamic regulation of bmi-1 expression in normal and leukemic hematopoietic cells. Stem Cells. 25:1635-1644. http://dx.doi.org/10 .1634/stemcells.2006-0229

Irish, J.M., D.K. Czerwinski, G.P. Nolan, and R. Levy. 2006. Altered B-cell receptor signaling kinetics distinguish human follicular lymphoma B cells from tumor-infiltrating nonmalignant B cells. Blood. 108:31353142. http://dx.doi.org/10.1182/blood-2006-02-003921

Jacobs, J.J., K. Kieboom, S. Marino, R.A. DePinho, and M. van Lohuizen. 1999. The oncogene and Polycomb-group gene bmi-1 regulates cell proliferation and senescence through the ink4a locus. Nature. 397:164168. http://dx.doi.org/10.1038/16476

Jima, D.D., R.N. Shah, T.M. Orcutt, D. Joshi, J.M. Law, G.W. Litman, N.S Trede, and J.A.Yoder. 2009. Enhanced transcription of complement and coagulation genes in the absence of adaptive immunity. Mol. Immunol. 46:1505-1516. http://dx.doi.org/10.1016/j.molimm.2008.12.021

Klein, A.M., L. Mazutis, I. Akartuna, N. Tallapragada, A.Veres,V. Li, L. Peshkin, D.A.Weitz, and M.W. Kirschner. 2015. Droplet barcoding for single-cell transcriptomics applied to embryonic stem cells. Cell. 161:1187-1201. http://dx.doi.org/10.1016/j.cell.2015.04.044

Kotecha, N., N.J. Flores, J.M. Irish, E.F. Simonds, D.S. Sakai, S. Archambeault, E. Diaz-Flores, M. Coram, K.M. Shannon, G.P. Nolan, and M.L. Loh. 2008. Single-cell profiling identifies aberrant STAT5 activation in myeloid malignancies with specific clinical and biologic correlates. Cancer Cell. 14:335-343. http://dx.doi.org/10.1016/j.ccr.2008.08.014

Lacayo, N.J., T.A. Alonzo, U. Gayko, D.B. Rosen, M. Westfall, N. Purvis, S Putta, B. Louie, J. Hackett, A.C. Cohen, et al. 2013. Development and validation of a single-cell network profiling assay-based classifier to predict response to induction therapy in paediatric patients with de novo acute myeloid leukaemia: a report from the Children's Oncology Group Br. J. Haematol. 162:250-262. http://dx.doi.org/10.1111/bjh.12370

Lahortiga, I., K. De Keersmaecker, P.Van Vlierberghe, C. Graux, B. Cauwelier, F. Lambert, N. Mentens, H.B. Beverloo, R. Pieters, F. Speleman, et al. 2007. Duplication of the MYB oncogene in T cell acute lymphoblastic leukemia. Nat. Genet. 39:593-595. http://dx.doi.org/10.1038/ng2025

Langenau, D.M., D. Traver, A.A. Ferrando, J.L. Kutok, J.C. Aster, J.P. Kanki, S. Lin, E. Prochownik, N.S. Trede, L.I. Zon, and A.T. Look. 2003. Myc- induced T cell leukemia in transgenic zebrafish. Science. 299:887-890. http://dx.doi.org/10.1126/science. 1080280

Langenau, D.M., A.A. Ferrando, D. Traver, J.L. Kutok, J.P. Hezel, J.P. Kanki, L.I. Zon, A.T. Look, and N.S. Trede. 2004. In vivo tracking of T cell development, ablation, and engraftment in transgenic zebrafish. Proc. Natl. Acad. Sci. USA. 101:7369-7374. http://dx.doi.org/10.1073/pnas .0402248101

Langenau, D.M., H. Feng, S. Berghmans, J.P. Kanki, J.L. Kutok, and A. T. Look. 2005. Cre/lox-regulated transgenic zebrafish model with conditional myc-induced T cell acute lymphoblastic leukemia. Proc. Natl. Acad. Sci. USA. 102:6068-6073. http://dx.doi.org/10.1073/pnas.0408708102

Langfelder, P., and S. Horvath. 2008. WGCNA: an R package for weighted correlation network analysis. BMC Bioinformatics. 9:559. http://dx.doi .org/10.1186/1471-2105-9-559

Lessard, J., and G. Sauvageau. 2003. Bmi-1 determines the proliferative capacity of normal and leukaemic stem cells. Nature. 423:255-260. http ://dx.doi.org/10.1038/nature01572

Levine, J.H., E.F. Simonds, S.C. Bendall, K.L. Davis, A.D. Amir, M.D. Tadmor, O. Litvin, H.G. Fienberg, A. Jager, E.R. Zunder, et al. 2015. DataDriven Phenotypic Dissection of AML Reveals Progenitor-like Cells that Correlate with Prognosis. Cell. 162:184-197. http://dx.doi.org/10 .1016/j.cell.2015.05.047

Lin, H.F., D. Traver, H. Zhu, K. Dooley, B.H. Paw, L.I. Zon, and R.I. Handin. 2005. Analysis of thrombocyte development in CD41-GFP transgenic zebrafish. Blood. 106:3803-3810. http://dx.doi.org/10.1182/blood -2005-01-0179

Litjens, N.H., E.A. de Wit, C.C. Baan, and M.G. Betjes. 2013. Activationinduced CD137 is a fast assay for identification and multi-parameter flow cytometric analysis of alloreactive $\mathrm{T}$ cells. Clin. Exp. Immunol. 174:179-191. http://dx.doi.org/10.1111/cei.12152

Ma, D., J. Zhang, H.F. Lin, J. Italiano, and R.I. Handin. 2011.The identification and characterization of zebrafish hematopoietic stem cells. Blood. 118:289-297. http://dx.doi.org/10.1182/blood-2010-12-327403

Ma, D., L. Wang, S. Wang, Y. Gao, Y. Wei, and F. Liu. 2012. Foxn1 maintains thymic epithelial cells to support T-cell development via $\mathrm{mcm} 2$ in zebrafish. Proc. Natl. Acad. Sci. USA. 109:21040-21045. http://dx.doi .org/10.1073/pnas.1217021110

Macosko, E.Z., A. Basu, R. Satija, J. Nemesh, K. Shekhar, M. Goldman, I. Tirosh, A.R. Bialas, N. Kamitaki, E.M. Martersteck, et al. 2015. Highly Parallel Genome-wide Expression Profiling of Individual Cells Using Nanoliter Droplets. Cell. 161:1202-1214. http://dx.doi.org/10.1016/j .cell.2015.05.002

Mansour, M.R., B.J. Abraham, L. Anders, A. Berezovskaya, A. Gutierrez, A.D. Durbin, J. Etchin, L. Lawton, S.E. Sallan, L.B. Silverman, et al. 2014. Oncogene regulation. An oncogenic super-enhancer formed through somatic mutation of a noncoding intergenic element. Science. 346:13731377. http://dx.doi.org/10.1126/science. 1259037

Mathias, J.R., B.J. Perrin, T.X. Liu, J. Kanki, A.T. Look, and A. Huttenlocher. 2006. Resolution of inflammation by retrograde chemotaxis of neutrophils in transgenic zebrafish. J. Leukoc. Biol. 80:1281-1288. http:// dx.doi.org/10.1189/jlb.0506346

Minegishi, N., S. Morita, M. Minegishi, S. Tsuchiya, T. Konno, N. Hayashi, and M. Yamamoto. 1997. Expression of GATA transcription factors in myelogenous and lymphoblastic leukemia cells. Int. J. Hematol. 65:239249. http://dx.doi.org/10.1016/S0925-5710(96)00553-1

Moignard,V., I.C. Macaulay, G. Swiers, F. Buettner, J. Schütte, FJ. Calero-Nieto, S. Kinston, A. Joshi, R. Hannah, FJ. Theis, et al. 2013. Characterization of transcriptional networks in blood stem and progenitor cells using highthroughput single-cell gene expression analysis. Nat. Cell Biol. 15:363372. http://dx.doi.org/10.1038/ncb2709

Mucenski, M.L., K. McLain, A.B. Kier, S.H. Swerdlow, C.M. Schreiner, T.A. Miller, D.W. Pietryga, W.J. Scott Jr., and S.S. Potter. 1991. A functional 
c-myb gene is required for normal murine fetal hepatic hematopoiesis. Cell. 65:677-689. http://dx.doi.org/10.1016/0092-8674(91)90099-K

North,T.E.,W. Goessling, C.R.Walkley, C. Lengerke, K.R. Kopani,A.M. Lord, G.J. Weber, T.V. Bowman, I.H. Jang, T. Grosser, et al. 2007. Prostaglandin E2 regulates vertebrate haematopoietic stem cell homeostasis. Nature. 447:1007-1011. http://dx.doi.org/10.1038/nature05883

Page, D.M.,V.Wittamer, J.Y. Bertrand, K.L. Lewis, D.N. Pratt, N. Delgado, S.E. Schale, C. McGue, B.H. Jacobsen, A. Doty, et al. 2013. An evolutionarily conserved program of B-cell development and activation in zebrafish. Blood. 122:e1-e11. http://dx.doi.org/10.1182/blood-2012-12-471029

Peña, S.V., D.A. Hanson, B.A. Carr, T.J. Goralski, and A.M. Krensky. 1997. Processing, subcellular localization, and function of 519 (granulysin), a human late $\mathrm{T}$ cell activation molecule with homology to small, lytic, granule proteins. J. Immunol. 158:2680-2688.

Pereiro, P., M.Varela, P. Diaz-Rosales, A. Romero, S. Dios, A. Figueras, and B. Novoa. 2015. Zebrafish Nk-lysins: First insights about their cellular and functional diversification. Dev. Comp. Immunol. 51:148-159. http://dx .doi.org/10.1016/j.dci.2015.03.009

Petrie-Hanson, L., C. Hohn, and L. Hanson. 2009. Characterization of rag1 mutant zebrafish leukocytes. BMC Immunol. 10:8. http://dx.doi.org/10 $.1186 / 1471-2172-10-8$

Pietrangelo, A. 2004. The ferroportin disease. Blood Cells Mol. Dis. 32:131138. http://dx.doi.org/10.1016/j.bcmd.2003.08.003

Riddell, J., R. Gazit, B.S. Garrison, G. Guo, A. Saadatpour, P.K. Mandal, W. Ebina, P. Volchkov, G.C. Yuan, S.H. Orkin, and D.J. Rossi. 2014. Reprogramming committed murine blood cells to induced hematopoietic stem cells with defined factors. Cell. 157:549-564. http ://dx.doi.org/10.1016/j.cell.2014.04.006

Ridges, S., W.L. Heaton, D. Joshi, H. Choi, A. Eiring, L. Batchelor, P. Choudhry, E.J. Manos, H. Sofla, A. Sanati, et al. 2012. Zebrafish screen identifies novel compound with selective toxicity against leukemia. Blood. 119:5621-5631. http://dx.doi.org/10.1182/blood-2011-12 $-398818$

Saadatpour, A., G. Guo, S.H. Orkin, and G.C. Yuan. 2014. Characterizing heterogeneity in leukemic cells using single-cell gene expression analysis. Genome Biol. 15:525. http://dx.doi.org/10.1186/s13059-014-0525-9

Sandberg, M.L., S.E. Sutton, M.T. Pletcher, T. Wiltshire, L.M. Tarantino, J.B. Hogenesch, and M.P. Cooke. 2005. c-Myb and p300 regulate hematopoietic stem cell proliferation and differentiation. Dev. Cell. 8:153-166. http://dx.doi.org/10.1016/j.devcel.2004.12.015

Satija, R., J.A. Farrell, D. Gennert, A.F. Schier, and A. Regev. 2015. Spatial reconstruction of single-cell gene expression data. Nat. Biotechnol. 33:495-502. http://dx.doi.org/10.1038/nbt.3192

Saudy, N.S., I.M. Fawzy, E. Azmy, E.F. Goda, A. Eneen, and E.M.Abdul Salam. 2014. BMI1 gene expression in myeloid leukemias and its impact on prognosis. Blood Cells Mol. Dis. 53:194-198. http://dx.doi.org/10.1016 /j.bcmd.2014.07.002

Sayitoğlu, M., Y. Erbilgin, O. Hatırnaz Ng, I. Yıldız, T. Celkan, S. Anak, O. Devecioğlu, G. Aydoğan, S. Karaman, N. Sarper, et al. 2012. Upregulation of T-Cell-Specific Transcription Factor Expression in Pediatric T-Cell Acute Lymphoblastic Leukemia (T-ALL). Turk. J. Haematol. 29:325-333. http://dx.doi.org/10.5505/tjh.2012.13540

Sen, N., G. Mukherjee, A. Sen, S.C. Bendall, P. Sung, G.P. Nolan, and A.M Arvin. 2014. Single-cell mass cytometry analysis of human tonsil T cell remodeling by varicella zoster virus. Cell Reports. 8:633-645. http://dx .doi.org/10.1016/j.celrep.2014.06.024

Shalek, A.K., R. Satija, X. Adiconis, R.S. Gertner, J.T. Gaublomme, R. Raychowdhury, S. Schwartz, N. Yosef, C. Malboeuf, D. Lu, et al. 2013. Single-cell transcriptomics reveals bimodality in expression and splicing in immune cells. Nature. 498:236-240. http://dx.doi.org/10.1038/ nature 12172

Shalek, A.K., R. Satija, J. Shuga, J.J. Trombetta, D. Gennert, D. Lu, P. Chen, R.S. Gertner, J.T. Gaublomme, N. Yosef, et al. 2014. Single-cell RNAseq reveals dynamic paracrine control of cellular variation. Nature. 510:363-369.

Shinkai,Y., G. Rathbun, K.P. Lam, E.M. Oltz, V. Stewart, M. Mendelsohn, J. Charron, M. Datta, F. Young, A.M. Stall, et al. 1992. RAG-2-deficient mice lack mature lymphocytes owing to inability to initiate $\mathrm{V}(\mathrm{D})$ J rearrangement. Cell. 68:855-867. http://dx.doi.org/10.1016/0092 $-8674(92) 90029-\mathrm{C}$

Smith, A.C., A.R. Raimondi, C.D. Salthouse, M.S. Ignatius, J.S. Blackburn, I.V. Mizgirev, N.Y. Storer, J.L. de Jong, A.T. Chen, Y. Zhou, et al. 2010. High-throughput cell transplantation establishes that tumor-initiating cells are abundant in zebrafish T-cell acute lymphoblastic leukemia. Blood. 115:3296-3303. http://dx.doi.org/10.1182/blood-2009-10 $-246488$

Tamplin, O.J., E.M. Durand, L.A. Carr, S.J. Childs, E.J. Hagedorn, P. Li, A.D. Yzaguirre, N.A. Speck, and L.I. Zon. 2015. Hematopoietic stem cell arrival triggers dynamic remodeling of the perivascular niche. Cell. 160:241-252. http://dx.doi.org/10.1016/j.cell.2014.12.032

Tang, Q., N.S. Abdelfattah, J.S. Blackburn, J.C. Moore, S.A. Martinez, F.E. Moore, R. Lobbardi, I.M. Tenente, M.S. Ignatius, J.N. Berman, et al 2014. Optimized cell transplantation using adult rag2 mutant zebrafish. Nat. Methods. 11:821-824. http://dx.doi.org/10.1038/nmeth.3031

Traver, D., B.H. Paw, K.D. Poss, W.T. Penberthy, S. Lin, and L.I. Zon. 2003. Transplantation and in vivo imaging of multilineage engraftment in zebrafish bloodless mutants. Nat. Immunol. 4:1238-1246. http://dx.doi .org/10.1038/ni1007

van Grotel, M., J.P. Meijerink, E.R. van Wering, A.W. Langerak, H.B Beverloo, J.G. Buijs-Gladdines, N.B. Burger, M. Passier, E.M. van Lieshout, W.A. Kamps, et al. 2008. Prognostic significance of molecularcytogenetic abnormalities in pediatric T-ALL is not explained by immunophenotypic differences. Leukemia. 22:124-131. http://dx.doi .org/10.1038/sj.leu. 2404957

Villa, A., S. Santagata, F. Bozzi, L. Imberti, and L.D. Notarangelo. 1999. Omenn syndrome: a disorder of Rag1 and Rag2 genes. J. Clin. Immunol. 19:87-97. http://dx.doi.org/10.1023/A:1020550432126

Wang, B., G.A. Hollander, A. Nichogiannopoulou, S.J. Simpson, J.S. Orange, J.C. Gutierrez-Ramos, S.J. Burakoff, C.A. Biron, and C. Terhorst. 1996. Natural killer cell development is blocked in the context of aberrant T lymphocyte ontogeny. Int. Immunol. 8:939-949. http://dx.doi.org/10 $.1093 /$ intimm/8.6.939

Wienholds, E., S. Schulte-Merker, B. Walderich, and R.H. Plasterk. 2002. Target-selected inactivation of the zebrafish rag1 gene. Science. 297:99102. http://dx.doi.org/10.1126/science.1071762

Wilson, N.K., D.G. Kent, F. Buettner, M. Shehata, I.C. Macaulay, FJ. CaleroNieto, M. Sánchez Castillo, C.A. Oedekoven, E. Diamanti, R. Schulte, et al. 2015. Combined Single-Cell Functional and Gene Expression Analysis Resolves Heterogeneity within Stem Cell Populations. Cell Stem Cell. 16:712-724. http://dx.doi.org/10.1016/j.stem.2015.04.004

Ye, J., G. Coulouris, I. Zaretskaya, I. Cutcutache, S. Rozen, and T.L. Madden. 2012. Primer-BLAST: a tool to design target-specific primers for polymerase chain reaction. BMC Bioinformatics. 13:134. http://dx.doi .org/10.1186/1471-2105-13-134

Yeh, J.R., K.M. Munson, K.E. Elagib, A.N. Goldfarb, D.A. Sweetser, and R.T. Peterson. 2009. Discovering chemical modifiers of oncogene-regulated hematopoietic differentiation. Nat. Chem. Biol. 5:236-243. http://dx.doi .org/10.1038/nchembio.147 